UNIVERSIDADE DE SÃO PAULO

ESCOLA DE EDUCAÇÃO FÍSICA E ESPORTE

\title{
EFEITO AGUDO DE DIFERENTES VELOCIDADES DE EXERCÍCIO EXCÊNTRICO NA SINALIZAÇÃO DA HIPERTROFIA MUSCULAR
}

Hamilton Roschel

SÃO PAULO

2009 
EFEITO AGUDO DE DIFERENTES VELOCIDADES DE EXERCÍCIO EXCÊNTRICO NA SINALIZAÇÃO DA HIPERTROFIA MUSCULAR

HAMILTON ROSCHEL

Tese apresentada à Escola de Educação Física

e Esporte da Universidade de São Paulo, como requisito parcial para obtenção do grau de Doutor em Educação Física.

ORIENTADOR: PROF. DR. VALMOR TRICOLI 


\section{Roschel, Hamilton}

Efeito agudo de diferentes velocidades de exercício excêntrico na sinalização da hipertrofia muscular / Hamilton Roschel. - São Paulo: [s.n.], 2009.

$105 p$.

Tese (Doutorado) - Escola de Educação Física e Esporte da Universidade de São Paulo

Orientador: Prof. Dr. Valmor A. A. Tricoli

1.mTOR 2. Isocinético 3. Treinamento de força I. Título 


\section{AGRADECIMENTOS}

Agradeço aos Prof.Drs. Valmor Tricoli e Carlos Ugrinowitsch, orientador e co-orientador do trabalho, que aceitaram dividir suas genialidades e insanidades comigo neste período extremamente proveitoso de minha formação. Agradeço aos companheiros de laboratório (Mauro, Renato, Giba, Edu, Lili, Léo, Rodrigão, Lucas, Rômulo e Anderson) que contribuíram de maneira inestimável para o meu enriquecimento acadêmico e pessoal. Agradeço aos amigos do ICB e UNIFESP que tiveram uma participação decisiva na confecção do trabalho (Mario, Zanuto, Sal e Edu), ao Manoel pelo excelente trabalho nas coletas musculares e ao pessoal da CPG que sempre me socorreu nos apuros costumeiros ao longo do programa. Aproveito para agradecer aos Prof. Dr. Marco Túlio, à Prof. ${ }^{a}$ Dr. ${ }^{a}$ Carla Carvalho, Prof. ${ }^{a}$ Dr. ${ }^{a}$ Emiko Hirata e Prof. Dr. Marcelo Aoki pelas parcerias, sem as quais o trabalho não poderia ser concluído. Agradeço aos amigos Valmor, Carlos e Lancha Jr. por me trazerem até aqui e principalmente pela amizade desenvolvida e estimada ao longo dos anos.

Dedico este trabalho aos meus pais Amilton e Nancy Roschel, que sempre me apoiaram e me deram todas as condições de seguir na área acadêmica. Dedico também aos meus sobrinhos Filipe e Gustavo Roschel. Dedico este trabalho com um carinho especial ao meu amor, Ana Carolina Garcia. 


\section{SUMÁRIO}

Página

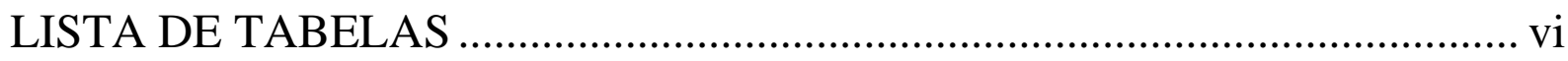

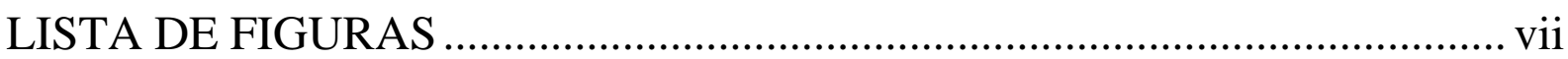

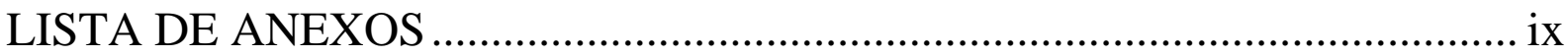

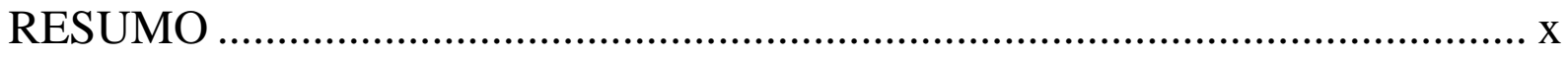

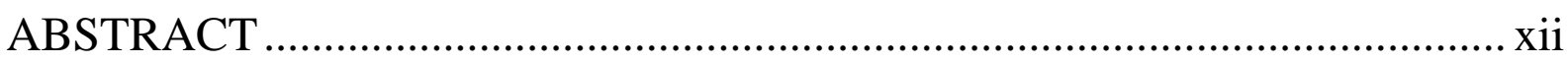

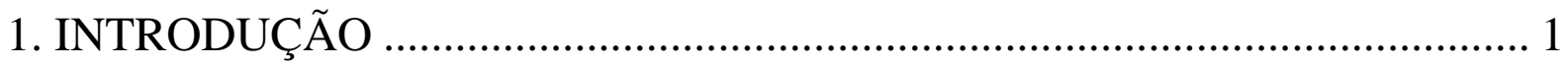

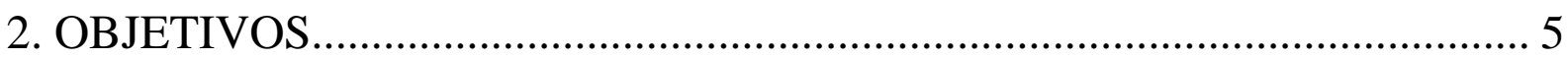

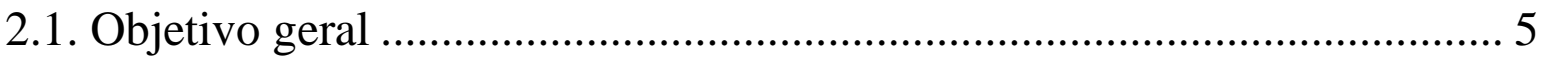

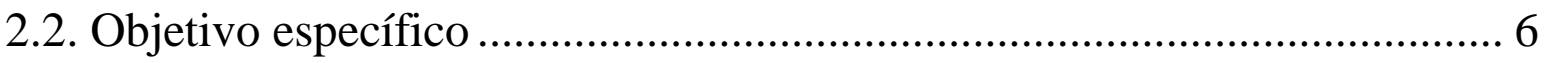

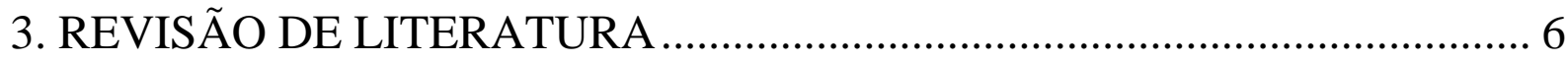

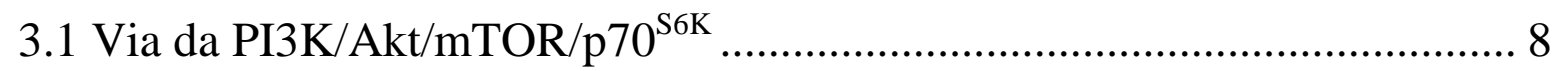

3.2 Estímulo mecânico e sinalização celular para hipertrofia ........................... 11

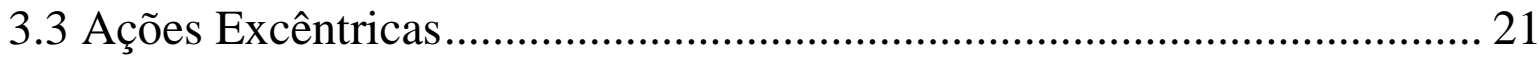

3.3.1 Modulação das ações excêntricas e ganhos de força e hipertrofia .. 26

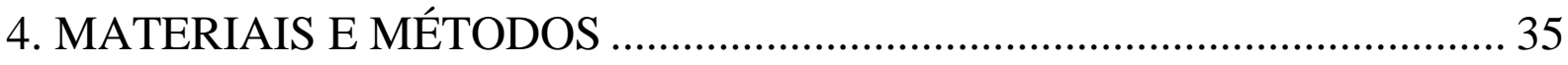

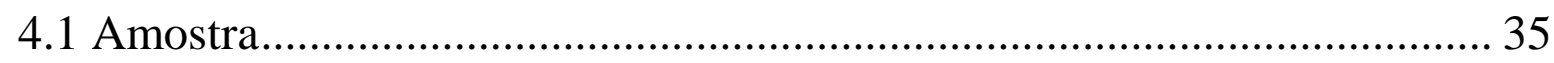


4.3 Monitoração do padrão alimentar dos sujeitos

4.7 Quantificação das proteínas Akt e p70 ${ }^{\mathrm{S} 6 \mathrm{~K}}$

4.7.1 Extração das proteínas totais dos músculos esqueléticos 43

4.7.2 Análise protéica por Immunoblotting 44

4.8 Determinação da expressão gênica de MGF e mTOR 45

4.8.1 Extração do RNA 45

4.8.2 RT-PCR 46

4.8.3 Método de detecção da expressão gênica em tempo real 47

4.9 Análise Estatística 48

5. RESULTADOS 49

5.1 Torque isométrico máximo 49

5.2 Pico de torque durante a sessão experimental 49

5.3 Trabalho produzido durante a sessão experimental. 50

5.4 Impulso produzido durante a sessão experimental 51

5.5 Quantificação das proteínas Akt total e Akt fosforilada (pAkt) 53

5.6 Quantificação das proteínas $\mathrm{p} 70^{\mathrm{S} 6 \mathrm{~K}}$ total e $\mathrm{p} 70^{\mathrm{S} 6 \mathrm{~K}}$ fosforilada 54 
5.7 Expressão gênica de MGF. 55

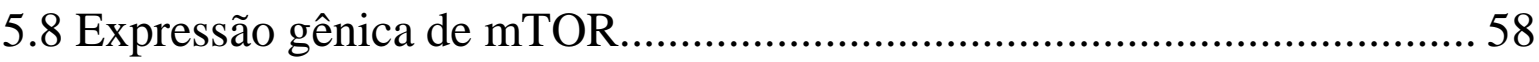

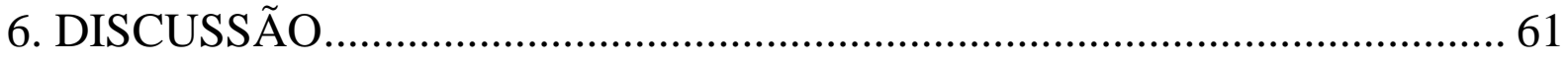

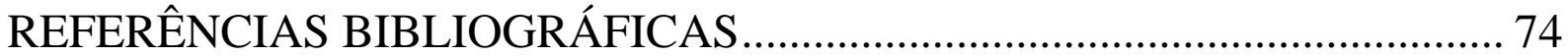




\section{LISTA DE TABELAS}

Página

TABELA 1 -.... Características das três diferentes ações musculares................. 22

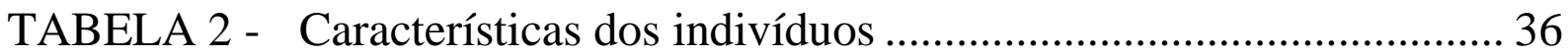

TABELA 3 - Ingestão nutricional pré sessão controle (CTL) e sessão

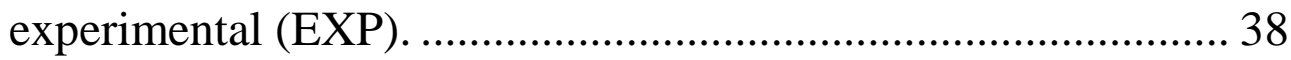




\section{LISTA DE FIGURAS}

Página

FIGURA 1 - Vias de sinalização da hipertrofia............................................... 10

FIGURA 2 - Curva força $x$ comprimento do sarcômero ................................... 23

FIGURA 3 - Curva força $x$ velocidade de contração........................................ 25

FIGURA 4 - Linha temporal dos procedimentos experimentais ....................... 37

FIGURA 5 - Torque isométrico máximo para os grupos 20\% (Exc20) e

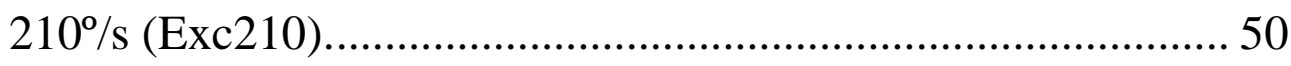

FIGURA 6 - Pico de torque em cada série de exercício excêntrico para os

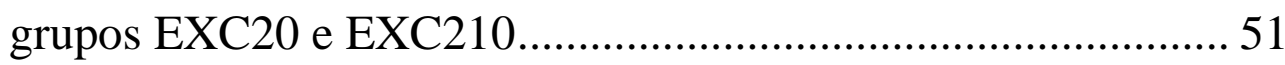

FIGURA 7 - Maior valor de pico de torque excêntrico para os grupos

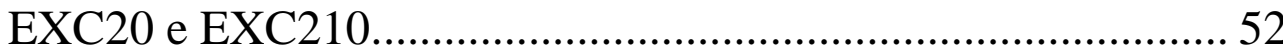

FIGURA 8 - Trabalho total produzido por cada grupo durante a sessão experimental 52

FIGURA 9 - Trabalho produzido por série de exercício durante a sessão experimental 53

FIGURA 10 - Impulso total produzido durante a sessão experimental. 54 
FIGURA 11 - Impulso produzido por série de exercício durante a sessão experimental 55

FIGURA 12 - Quantificação da proteína Akt total para os grupos EXC20 e EXC210 56

FIGURA 13 - Quantificação da proteína pAkt (Akt fosforilada) para os grupos EXC20 e EXC210.

FIGURA 14 - Quantificação da proteína p70 ${ }^{\mathrm{S} 6 \mathrm{~K}}$ total para os grupos EXC20 e EXC210. 58

FIGURA 15 - Quantificação da proteína $\mathrm{p} 70^{\mathrm{S} 6 \mathrm{k}}$ fosforilada $\left(\mathrm{pp} 70^{\mathrm{S} 6 \mathrm{~K}}\right)$ para os grupos EXC 20 e EXC210.

FIGURA 16 - Expressão gênica de MGF 60

FIGURA 17 - Expressão gênica de mTOR 61 


\section{LISTA DE ANEXOS}

Página

ANEXO 1 - Questionário de avaliação do nível de treinamento dos sujeitos.....91 


\title{
RESUMO
}

\section{EFEITO AGUDO DE DIFERENTES VELOCIDADES DE EXERCÍCIO EXCÊNTRICO NA SINALIZAÇÃO DA HIPERTROFIA MUSCULAR}

\author{
Autor: Hamilton Roschel \\ Orientador: Prof. Dr. Valmor Tricoli
}

Atualmente, alguns pesquisadores tem se dedicado ao estudo do efeito da manipulação do treinamento de força sobre a ativação das vias de sinalização intracelular para hipertrofia. Tem-se sugerido que o grau de tensão muscular desempenhe um papel importante nesta sinalização. Dentre os diferentes tipos de ações musculares, as ações excêntricas (AE) reconhecidamente proporcionam maior grau de tensão à estrutura do músculo esquelético. Em particular, $\mathrm{AE}$ de alta velocidade parecem exercer um efeito interessante sobre os ganhos de hipertrofia muscular. Porém, pouco se sabe sobre o efeito da manipulação da velocidade sobre as vias de sinalização da hipertrofia. Assim, o presente estudo teve como objetivo verificar o efeito agudo da $\mathrm{AE}$ de alta e baixa velocidade 
sobre a sinalização para hipertrofia muscular. Vinte sujeitos foram aleatoriamente divididos em dois grupos. Um realizou cinco séries de oito $\mathrm{AE}$ máximas à $20 \%$ s (EXC20) e o outro à $210^{\circ} \%$ s (EXC210) do exercício extensão de joelhos. Amostras do músculo vasto lateral foram obtidas antes, imediatamente após e duas horas após o exercício. As análises de quantificação protéica de Akt e $\mathrm{p} 70^{\mathrm{S} 6 \mathrm{~K}}$ totais não apresentaram diferenças significantes intra ou inter grupos. A avaliação da fosforilação das mesmas proteínas revelou um efeito principal de tempo, indicando um aumento da fosforilação nos tempos imediatamente após e duas horas após o término do exercício em relação à amostra controle $(\mathrm{p}<0,05)$, porém não foram observadas diferenças entre os grupos. Para os dados de expressão gênica de MGF e mTOR, não foram observadas diferenças intra ou inter grupos. Em conclusão, a manipulação aguda da velocidade das AE parece não influenciar a fosforilação ou expressão gênica das proteínas em questão.

Palavras-chave: mTOR, isocinético, treinamento de força. 


\begin{abstract}
EFFECT OF AN ACUTE BOUT OF ECCENTRIC EXERCISE AT DIFFERENT VELOCITIES ON MUSCLE HYPERTROPHY SIGNALING
\end{abstract}

\author{
Author: Hamilton Roschel \\ Adviser: Prof. Dr. Valmor Tricoli
}

Recently, many studies have focused on the effects of strength training variables manipulation on the activation of intracellular signaling pathways for skeletal muscle hypertrophy. It has been suggested that the muscle tension plays a major role in such process. Eccentric muscle actions (EE) are notorious for imposing a greater amount of tension on the active muscle. In particular, EE performed at high velocities seems to exert an interesting effect on hypertrophy gains. However, little is known about the effect of EE velocity manipulation on hypertrophy pathways signaling. Thus, the present study aimed to investigate the acute effect of low and high velocity EE on muscle hypertrophy signaling. Twenty subjects were randomly assigned to either a slow velocity group $-20 \%$ 
(ECC20) or fast group $-210 \%$ s (ECC210). Muscle biopsy samples were taken before, immediately after and two hours after the completion of five sets of eight maximal repetitions at the designated velocity, knee extension exercise. Akt and $\mathrm{p} 70^{\mathrm{S} 6 \mathrm{~K}}$ analysis did not reveal any differences inter or intra groups. Akt and $\mathrm{p} 70^{\mathrm{S} 6 \mathrm{~K}}$ phosphorylation results indicated a main effect for time $(\mathrm{p}<0,05)$, with increased phosphorylation values for immediately after and two hours after time points in comparison to control samples. MGF and mTOR mRNA analysis did not return any inter or intra groups differences. In conclusion, the acute manipulation of EE velocity does not seem to differently influence the phosphorylation or expression of the proteins studied.

Keywords: mTOR, isokinetic, strength training 


\section{INTRODUÇÃO}

O músculo esquelético é um tecido altamente plástico, possuindo a capacidade de se adaptar a diferentes tipos de estímulos, desde alterações na atividade neuromuscular, passando pela sobrecarga e até a disponibilidade de substratos. Essa capacidade de adaptação às diferentes demandas funcionais é específica ao tipo de estímulo recebido. Alguns exemplos destas adaptações podem ser notados quando os indivíduos são submetidos a diferentes situações como treinamento de força, treinamento de resistência aeróbia ou até mesmo repouso absoluto e imobilização.

Quando o músculo é submetido a um estímulo como o apresentado pelo treinamento de força $(\mathrm{TF})$, as principais adaptações são o aumento da força muscular e da área da secção transversa do músculo (hipertrofia). A manipulação e o controle das variáveis do treinamento de força, tais como, o tipo e a velocidade da ação muscular empregadas, a intensidade da carga e o volume de treino são feitas com o objetivo de otimizar as respostas fisiológicas ao programa de treinamento e, assim, contribuir para a melhora do desempenho motor.

Um bom exemplo do exposto anteriormente é a suposta superioridade da ação excêntrica (AE) em estimular a hipertrofia muscular em comparação às ações concêntricas (HIGBIE, CURETON, WARREN \& PRIOR, 1996; HORTOBAGYI, BARRIER, BEARD, BRASPENNINCX, KOENS, DEVITA, 
DEMPSEY \& LAMBERT, 1996; SEGER, ARVIDSSON \& THORSTENSSON, 1998). Uma explicação para o fenômeno poderia estar relacionada à maior tensão desenvolvida pelas AE em comparação as concêntricas (JOUMAA, RASSIER, LEONARD \& HERZOG, 2008). De forma ainda mais interessante, a velocidade das AE parece desempenhar um papel importante neste processo. FARTHING e CHILIBECK (2003) observaram maiores ganhos de força e de hipertrofia quando AE de alta velocidade foram utilizadas. SHEPSTONE, TANG, DALLAIRE, SCHUENKE, STARON e PHILLIPS (2005) corroboraram estes achados, reportando também maiores ganhos de força e de hipertrofia para o grupo que treinou com AE velozes. Estes autores citam ainda que tais resultados devem-se possivelmente à maior remodelação protéica causada pelas $\mathrm{AE}$ em alta velocidade. Em outro estudo, PADDON-JONES, LEVERITT, LONERGAN e ABERNETHY (2001) embora não tenham investigado o efeito da velocidade das ações musculares na hipertrofia, mostraram que a manipulação da velocidade das AE, pode modular significantemente os ganhos de força.

Numa tentativa de explicar estes achados, CHAPMAN, NEWTON, MCGUIGAN e NOSAKA (2008) argumentam que a manipulação da velocidade das AE poderia resultar em um estímulo tensional de maior magnitude, favorecendo, em tese, a ocorrência do dano muscular, o qual, segundo MORGAN e PARTRIDGE (2003), poderia induzir um maior grau de hipertrofia crônica. 
Contudo, dados de nosso laboratório ainda não publicados, assim como um trabalho recente (CHAPMAN et al., 2008), mostram que a manipulação da velocidade parece não exercer efeito sobre a magnitude do dano muscular. Adicionalmente, um fenômeno denominado efeito da carga repetida (ECR) parece diminuir a importância da lesão celular no processo crônico de hipertrofia, uma vez que estudos têm demonstrado que o grau de dano muscular parece diminuir sensivelmente nas sessões subsequentes ao estímulo inicial (NOSAKA \& CLARKSON, 1995; NOSAKA, SAKAMOTO, NEWTON \& SACCO, 2001). Parece haver, portanto, outro mecanismo responsável pela maior hipertrofia muscular observada com a utilização de $\mathrm{AE}$ em alta velocidade que não o dano muscular.

Recentemente tem-se dado grande importância ao estudo das vias de sinalização de eventos celulares decorrentes do exercício físico, e dentre elas, a sinalização intracelular da hipertrofia muscular recebe particular destaque.

A via da PI3K/Akt/mTOR/p $70^{\mathrm{S} 6 \mathrm{~K}}$ tem sido amplamente atribuída como um dos principais controladores do crescimento celular (NADER, MCLOUGHLIN \& ESSER, 2005; SCHMELZLE \& HALL, 2000). Além disso, a atividade da via parece ser necessária para a hipertrofia estimulada pela tensão muscular (BODINE, STITT, GONZALEZ, KLINE, STOVER, BAUERLEIN, ZLOTCHENKO, SCRIMGEOUR, LAWRENCE, GLASS \& YANCOPOULOS, 
2001; NADER, MCLOUGHLIN \& ESSER, 2005) uma vez que estudos utilizando rapamicina, um potente inibidor da mTOR, mostraram inibição da hipertrofia muscular induzida tanto pela tensão, em modelos in vivo (BODINE et al., 2001), quanto pela administração de IGF1, em modelos in vitro (ROMMEL, BODINE, CLARKE, ROSSMAN, NUNEZ, STITT, YANCOPOULOS \& GLASS, 2001).

CORRADETTI e GUAN (2006) em recente revisão destacam a importância desta via como regulador da tradução no processo de síntese protéica. Os autores citam ainda que um dos mecanismos pelo qual ela exerce tal regulação é através da fosforilação de um regulador chave da tradução, a p70 ${ }^{\mathrm{S} 6 \mathrm{~K}}$. Assim, é de grande interesse é o efeito da manipulação do estímulo externo na fosforilação de proteínas sinalizadoras da hipertrofia.

Estudos recentes têm mostrado que o treinamento de força fosforila de maneira evidente a proteína p70 ${ }^{\mathrm{S} 6 \mathrm{~K}}$ (KOOPMAN, ZORENC, GRANSIER, CAMERON-SMITH \& VAN LOON， 2006; TERZIS， GEORGIADIS, STRATAKOS, VOGIATZIS, KAVOURAS, MANTA, MASCHER \& BLOMSTRAND, 2008), e tal fosforilação tem relação com o aumento de massa muscular resultante deste tipo de treinamento (BAAR \& ESSER, 1999; TERZIS et al., 2008). De forma ainda mais interessante, AE parecem ser mais capazes de estimular a via mTOR/p70 ${ }^{\mathrm{S} 6 \mathrm{~K}}$ em comparação às ações concêntricas (BURRY, 
HAWKINS \& SPANGENBURG, 2007; ELIASSON, ELFEGOUN, NILSSON, KOHNKE, EKBLOM \& BLOMSTRAND, 2006; SPANGENBURG \& MCBRIDE, 2006), permitindo inferir a importância da tensão muscular no processo de ativação da via.

De fato, a tensão parece exercer um papel importante, uma vez que um dos iniciadores da cascata de sinalização, o MGF (mechano growth factor) é sensível à tensão produzida no tecido muscular (TIDBALL, 2005). Adicionalmente, HEINEMEIER， OLESEN， SCHJERLING， HADDAD， LANGBERG, BALDWIN e KJAER (2007b) demonstraram que AE são mais potentes estimuladores para o aumento da expressão de MGF do que ações concêntricas.

Desta forma, parece razoável hipotetizar que, se de fato as $\mathrm{AE}$ de alta velocidade exercem maior tensão sobre o tecido muscular, estas seriam capazes, também, de promover maior ativação de proteínas chave da regulação das vias de sinalização da hipertrofia.

\section{OBJETIVOS}

\subsection{Objetivo geral}

Este trabalho teve como objetivo geral avaliar o efeito do exercício excêntrico agudo em diferentes velocidades sobre a ativação e expressão de 
proteínas específicas envolvidas na via PI3K/Akt/mTOR/p70 ${ }^{\mathrm{S}}$ de sinalização da hipertrofia do músculo esquelético.

\subsection{Objetivo específico}

Verificar o efeito agudo de uma sessão de exercício excêntrico em velocidades baixa $(20 \%$ s) ou alta $(210 \%)$ sobre:

- a fosforilação da proteína Akt

- a fosforilação da proteína $\mathrm{p} 70^{\mathrm{S} 6 \mathrm{~K}}$

- a expressão gênica de MGF e mTOR

\section{REVISÃO DE LITERATURA}

A hipertrofia muscular parece ser uma das adaptações ao treinamento de maior interesse na comunidade científica atualmente, uma vez que vários estudos têm tentado elucidar os mecanismos responsáveis pelo aumento da massa muscular, bem como o melhor paradigma de treinamento para otimizar tal efeito (ELIASSON et al., 2006; SPANGENBURG \& MCBRIDE, 2006).

A adaptação do músculo esquelético em resposta aos diferentes estímulos envolve a reprogramação da expressão gênica associada a alterações nas atividades de tradução e de turnover protéico, facilitando a remodelação estrutural (hipertrofia ou atrofia) ou transformação individual de fibras musculares 
(PARSONS, MILLAY, WILKINS, BUENO, TSIKA, NEILSON, LIBERATORE, YUTZEY, CRABTREE, TSIKA \& MOLKENTIN, 2004). Estas transformações envolvem aumento da síntese de proteínas contráteis, modificações na expressão das cadeias pesadas de miosina, nos componentes do sarcômero, nos aspectos metabólicos e nos fatores de utilização de oxigênio além de propriedades neuromusculares (PETTE \& STARON, 2000; SCHIAFFINO \& REGGIANI, 1994).

A fim de discutir os possíveis mecanismos desencadeadores destas transformações, BOLSTER, JEFFERSON e KIMBALL (2004) destacam a existência de uma vasta lista de vias de transdução de sinais externos para desencadear processos como: absorção de nutrientes, alterações metabólicas, transcrição de genes e tradução de mRNA. Usualmente, o maquinário de transdução do sinal consiste em um grupo de proteínas quinases atuando em forma de cascata até a sinalização final da via.

Uma via bastante comum de sinalização celular acionada pelo exercício físico, em particular pelo treinamento de força é a iniciada pela fosfatidil-inositol 3-quinase (PI3K). Estimulada pelo aumento nas concentrações de IGF e MGF (entre outros fatores) ela aciona em forma de cascata, entre outras, as seguintes proteínas: proteína quinase $\mathrm{B}$ (Akt ou $\mathrm{PKB})$, proteína alvo de rapamicina em mamíferos (mTOR) e proteína ribossomal 70 quinase S6 $\left(\mathrm{p} 70^{\mathrm{S} 6 \mathrm{~K}}\right)$. 


\subsection{Via da PI3K/Akt/mTOR/p70 ${ }^{\mathrm{S} 6 \mathrm{~K}}$}

CANTLEY (2002) classifica a PI3K como uma lipídeo quinase que fosforila o grupamento hidroxil da fosfatidil-inositol 4,5 difosfato, levando à produção de fosfatidil-inositol 3,4,5 trifosfato (PI-3,4,5-P3) na membrana plasmática. A PI-3,4,5-P3 recruta a Akt até a membrana plasmática, ativando-a. De maneira simplificada, a reação em sequência é a fosforilação da mTOR. A ativação da mTOR promove a fosforilação de uma variedade de substratos, incluindo a proteína de ligação eIF4E (4E-BP1) e a proteína p70 ${ }^{\mathrm{S} 6 \mathrm{~K}}$ (BOLSTER, JEFFERSON \& KIMBALL, 2004).

GLASS (2003) reporta que a ativação da mTOR resulta na tradução de proteínas por dois mecanismos distintos. O primeiro mecanismo passa pela ativação da $\mathrm{p} 70^{\mathrm{S} 6 \mathrm{~K}}$, considerado um regulador positivo da tradução protéica, pela mTOR. Tal ativação fosforila a proteína S6 na subunidade ribossomal 40S, promovendo a tradução de mRNA (KOOPMAN et al., 2006). O segundo mecanismo baseia-se na inibição da atividade de 4E-BP1 pela mTOR, a qual é conhecida como regulador negativo do fator de iniciação eIF-4E. O 4E-BP1, quando hiperfosforilado pela mTOR, se dissocia do complexo 4E-BP1 - eIF4E, permitindo a participação deste último no processo de iniciação da tradução, atuando no reconhecimento do cap na extremidade 5'do mRNA. (KOOPMAN et al., 2006). 
É importante notar que tanto KIMBALL, FARRELL e JEFFERSON (2002) quanto SARTORELLI e FULCO (2004) destacam a importância da insulina e do IGF/MGF na fosforilação da PI3K no início da cascata de sinalização. Contudo, embora a via da PI3K pareça ser o modelo mais comum de cascata para sinalização da hipertrofia, alguns estudos têm mostrado ativação da $\mathrm{p} 70^{\mathrm{S} 6 \mathrm{~K}}$ através do exercício físico, de maneira independente da PI3K. BOLSTER, JEFFERSON e KIMBALL (2004) sugerem que o exercício pode ativar a PI3K, a PDK1 (downstream na cascata de sinalização da PI3K) ou até mesmo a Akt/PKB de maneiras independentes (Figura 1). Contudo, a fosforilação de $\mathrm{p} 70^{\mathrm{S} 6 \mathrm{~K}}$ parece ser destino comum às rotas alternativas de sinalização. Adicionalmente, a ativação da mTOR foi mostrada em músculos submetidos a alongamento de maneira independente da Akt (ratos com gene nulo para expressão de Akt) (HORNBERGER, STUPPARD, CONLEY, FEDELE, FIOROTTO, CHIN \& ESSER, 2004). Similarmente, a ativação da $\mathrm{p} 70^{\mathrm{S} 6 \mathrm{~K}}$ foi demonstrada sob mesmo estímulo (alongamento intermitente) na presença de inibidor de PI3K, evidenciando a fosforilação desta proteína como destino comum à diferentes tipos de estímulos (HORNBERGER \& CHIEN, 2006).

Parece haver, portanto, uma redundância na sinalização para hipertrofia, onde estímulos distintos, através de caminhos alternativos e ainda não totalmente elucidados culminam na ativação do processo de síntese protéica. 


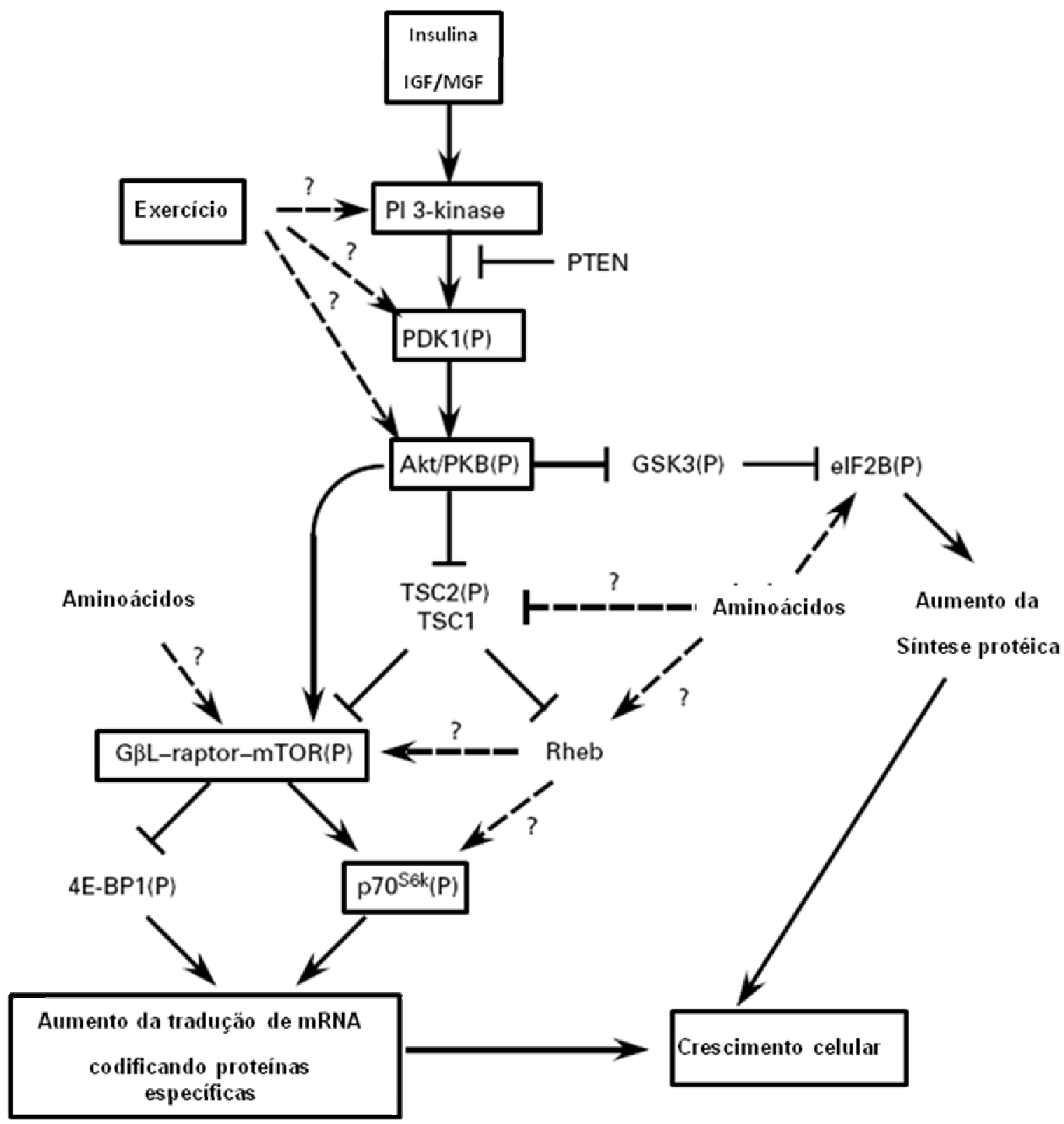

FIGURA 1 - Vias de sinalização da hipertrofia. Adaptado de BOLSTER, JEFFERSON e KIMBALL (2004). 


\subsection{Estímulo mecânico e sinalização celular para hipertrofia}

CARSON e WEI (2000) discutem que a transmissão da tensão pela estrutura do citoesqueleto do músculo tem a capacidade de influenciar a mudança na atividade e na expressão gênica de vários mecanismos de sinalização. TIDBALL (2005) em uma revisão bastante abrangente, destaca a importância da tensão muscular na liberação de IGF-1 (insulin like growth factor ou fator de crescimento semelhante à insulina) e na ativação da sinalização das vias de hipertrofia.

De fato, um estudo muito interessante reporta o efeito do exercício de força na produção de IGF-1 de maneira seletiva ao tipo de estímulo. HEINEMEIER et al. (2007b) utilizaram modelo animal e exercícios involuntários concêntricos, excêntricos ou isométricos por 4 dias para verificar a mudança na expressão gênica de IGF-1Ea (isoforma hepática) e MGF (isoforma muscular) em função da manipulação do estímulo mecânico. Ambos, IGF-1Ea e MGF aumentaram sua expressão no tecido muscular. Contudo, o dado mais interessante foi o fato do exercício excêntrico ter promovido aumentos significantemente maiores dos mesmos parâmetros (IGF-1Ea e MGF) em comparação ao modelo concêntrico, enquanto o modelo isométrico mostrou-se mais eficiente que o modelo concêntrico apenas para o IGF-1Ea. Estes dados corroboram as afirmações prévias da participação da tensão na modulação do IGF/MGF e do envolvimento 
de ambas isoformas na hipertrofia induzida pela sobrecarga mecânica (GOLDSPINK, 2005; ROMMEL et al., 2001; TIDBALL, 2005).

Contudo, os dados sobre MGF e IGF ainda são controversos, e não parece haver um padrão bem descrito da resposta destes fatores de crescimento frente aos diferentes tipos de ações musculares (GOLDSPINK, 2005). Além disso, a tensão muscular parece não só estimular o crescimento muscular ao aumentar a produção de fatores de crescimento (IGF-1, MGF), mas também ao desencadear o processo de sinalização pela alteração estrutural propiciada pela tensão muscular, convertendo energia mecânica em eventos biológicos (mecanotransdução) (TIDBALL, 2005).

A deformação celular ou molecular é o evento crítico no desencadeamento da mecanotransdução. Ou seja, para que ocorra a sinalização mecânica de uma perturbação, alguma estrutura tem que sofrer alteração. As mudanças estruturais mais diretamente ligadas ao músculo esquelético estão associadas às proteínas de adesão e ao aparato contrátil. Contudo, o sarcolema e o citoesqueleto também são passíveis de deformação (BURKHOLDER, 2007).

HORNBERGER e ESSER (2004) destacam a existência de vários candidatos a mecanorreceptores, mas os subdividem em duas categorias: bicamada lipídica e matriz extracelular-integrina-citoesqueleto. 
Durante uma deformação mecânica a rede de proteínas do citoesqueleto pode ser expandida e a bicamada lipídica (originalmente organizada em vilosidades) alongada, podendo gerar sua ruptura. A movimentação entre componentes intra e extracelulares pode atuar como mecanismos de mecanotransdução. Além disso, durante o processo de reparação da membrana, componentes vesiculares (intracelulares) podem ser liberados ao meio externo, desencadeando os processos de síntese protéica (HAMILL \& MARTINAC, 2001). Adicionalmente, a alteração da fluidez da membrana pela tensão pode causar ativação de proteínas G, ativando a via da PI3K (GUDI, NOLAN \& FRANGOS, 1998; WYMANN \& PIROLA, 1998).

Por outro lado, alguns trabalhos mostram que o citoesqueleto, em particular as proteínas de adesão focal (FAK) e o complexo distrofina, desempenham um papel importante na mecanotransdução (HORNBERGER \& ESSER, 2004).

As FAKs podem ser encontradas em estruturas localizadas acima das linhas Z, denominadas costâmeros. Proteínas específicas presentes nos costâmeros, as integrinas, tem sido creditadas como participantes no processo de ativação da mTOR em resposta ao estímulo mecânico. Já o complexo distrofina atuaria no controle da mecanotransdução ao fazer a ligação entre a membrana extracelullar e a actina através das proteínas $\alpha$-distroglicano e $\beta$-distroglicano (BOPPART, BURKIN \& KAUFMAN, 2006). 
Estas considerações revelam que existem maneiras diversas pelas quais a deformação mecânica possa ser convertida em um sinal bioquímico. Conforme sugerido anteriormente, a sinalização mecânica tem sido associada com o crescimento muscular, aumento da síntese protéica e liberação de fatores de crescimento (GOLDSPINK, 1999; RENNIE, WACKERHAGE, SPANGENBURG \& BOOTH, 2004; TIDBALL, 2005 ), e a ativação das cascatas de sinalização para hipertrofia, embora não totalmente compreendidas, podem ser consideradas efetores downstream da mecanotransdução (BURKHOLDER, 2007).

Vários estudos se dedicaram à investigação do papel do estímulo mecânico sobre a sinalização da hipertrofia, em particular pela via PI3K/Akt/mTOR/p70 ${ }^{\mathrm{S} 6 \mathrm{~K}}$. Em um trabalho com modelo animal utilzando ablação dos músculos sóleo e gastrocnêmio, os autores promoveram uma sobrecarga funcional no músculo plantar. Tal sobrecarga resultou em maior fosforilação da Akt e das proteínas downstream da mTOR como a 4E-BP1 e a S6K1 (BODINE et al., 2001).

Na mesma linha, BOLSTER, KUBICA, CROZIER, WILLIAMSON, FARRELL, KIMBALL e JEFFERSON (2003) verificaram que, em ratos submetidos a um modelo que contemplava tanto ações concêntricas quanto excêntricas (os animais foram condicionados a levantar e acionar uma barra iluminada posicionada na gaiola), enquanto a fosforilação de mTOR não se 
modificou, as proteínas downstream a ela (eIF4E, 4E-BP1 e p70 ${ }^{\mathrm{S} 6 \mathrm{~K}}$ ) mostraram suas fosforilações alteradas. A 4E-BP1 mostrou-se mais ativa 10 minutos pósexercício, enquanto a $\mathrm{p} 70^{\mathrm{S} 6 \mathrm{~K}}$ apresentou apenas uma tendência a maior atividade no mesmo momento. Contudo, a fosforilação da proteína ribossomal S6 mostrouse aumentada aos 15 minutos pós-estimulação. Segundo os autores, tais alterações estão relacionadas à resposta hipertrófica induzida pelo exercício.

Ainda utilizando modelos não fisiológicos de indução da tensão sobre o tecido muscular (alongamento in vivo), AOKI, MIYABARA, SOARES, SAITO e MORISCOT (2006) submeteram ratos Wistar a quatro dias de alongamento e 10 dias de administração de rapamicina. Os autores verificaram que o crescimento longitudinal e radial dos animais submetidos ao alongamento foram negativamente influenciados pela administração de rapamicina, apresentando incremento de apenas $11 \%$ e $15 \%$, respectivamente em comparação ao grupo sem rapamicina, que apresentou incrementos significantemente maiores (27\% e $25 \%$ respectivamente. Apesar da redundância na sinalização discutida anteriormente, os dados apontam para a importância da mTOR (inibida pela rapamicina) no crescimento muscular. SAKAMOTO, ASCHENBACH, HIRSHMAN e GOODYEAR (2003) também utilizaram um modelo de alongamento, porém os autores optaram por um modelo in vitro. $\mathrm{O}$ alongamento se mostrou eficiente em aumentar a atividade da Akt. Contudo, o efeito parece ser tipo de fibra 
dependente, sendo observado apenas em fibras de contração rápida. Embora os autores não discutam em profundidade as possíveis causas deste achado, BURKHOLDER (2007) traz à tona a diferença mecânica entre sobrecargas in vivo e in vitro, principalmente no que diz respeito à ausência de cargas de cisalhamento (transversais ao plano muscular) neste último, o que poderia representar um estímulo de natureza mecânica diferente ao fisiológico.

Em um modelo mais aplicado, KOOPMAN et al. (2006) submeteram sujeitos do sexo masculino a uma sessão aguda de treinamento de força. Amostras de tecido muscular foram obtidas imediatamente após e 30 e 120 minutos após o estímulo. Os autores observaram aumento da fosforilação da p $70^{\mathrm{S} 6 \mathrm{~K}}$ no período pós-exercício tanto em fibras do tipo I quanto do tipo II. Contudo, um aumento significantemente maior foi reportado para as fibras do tipo II. Os autores creditam a diferença à maior ativação das fibras tipo II durante estímulos de alta intensidade.

Em outro estudo bastante interessante, TERZIS et al. (2008) investigaram a relação entre a fosforilação de $\mathrm{p} 70^{\mathrm{S} 6 \mathrm{~K}}$ e o aumento de massa muscular após um período de treinamento de força. O estudo foi constituído por dois experimentos. A fase aguda envolveu biópsias pré e após 30 minutos a primeira sessão de treinamento de força. A fase crônica teve duração de 14 semanas. Os autores reportaram aumento da fosforilação tanto da mTOR quanto de $\mathrm{p} 70^{\mathrm{S} 6 \mathrm{~K}} 30$ minutos 
após a sessão aguda de exercícios de força. Além disso, os autores observaram uma boa correlação do aumento da $\mathrm{p} 70^{\mathrm{S} 6 \mathrm{~K}}(\mathrm{r}=0.82)$ com o percentual de aumento na massa livre de gordura no período pós-treinamento $(2,3 \%$, p<0,05).

BAAR e ESSER (1999) também observaram resultados similares, porém, estudando um modelo animal. Os autores submeteram os ratos a seis semanas de eletroestimulação de alta freqüência, e os resultados de aumento de massa muscular frente ao estímulo crônico de treinamento correlacionaram-se muito bem ( $\mathrm{r}=0.998)$ com o aumento na fosforilação de $\mathrm{p} 70^{\mathrm{S6K}}$ após uma sessão aguda de eletroestimulação.

Embora este último estudo retome a idéia de modelos experimentais um pouco mais distantes da aplicação direta, combinados, os dados de TERZIS et al. (2009) e BAAR e ESSER (1999) ilustram a relação entre o evento agudo de sinalização pela via, e o aumento crônico do tecido muscular, indicando a relevância do estudo dos efeitos do exercício sobre a fosforilação de proteínas chave da via em discussão.

Entretanto, parece que a manipulação do estímulo pode exercer um efeito modulatório interessante sobre a sinalização celular. Alguns estudos recentes e bastante elegantes discutem a relação entre o grau de ativação desta via e o tipo de ação muscular utilizado (BURRY, HAWKINS \& SPANGENBURG, 2007; ELIASSON et al., 2006). 
ELIASSON et al. (2006) usaram um modelo cross-over com múltiplas biópsias para comparar o efeito de ações musculares excêntricas e concêntricas desempenhadas de maneira máxima ou então equalizando o torque produzido, comparando ações concêntricas máximas com excêntricas submáximas. Para tal, quatro biópsias foram obtidas em cada perna (no modelo cross-over, cada perna executava um tipo de ação muscular por vez) nos tempos pré, imediatamente, 60 e 120 minutos após exercício. Quando comparadas as ações excêntricas e concêntricas desempenhadas em caráter máximo, a força produzida foi $31 \%$ maior para o exercício excêntrico. O exercício excêntrico resultou ainda, em maior fosforilação das proteínas $\mathrm{p} 70^{\mathrm{S} 6 \mathrm{~K}}$ e proteína ribossomal S6. Os valores se mantiveram elevados durante todo o período de avaliação pós-exercício (até 120 minutos). Contudo, nenhuma alteração na fosforilação da Akt e da mTOR foi verificada. Quando ações excêntricas submáximas e concêntricas máximas foram comparadas, os autores não verificaram alterações significantes em relação ao controle em nenhum dos tempos analisados. Os dados indicam que uma vez que os exercícios concêntrico máximo e excêntrico submáximo não foram capazes de aumentar a sinalização pela via, fica implícita a importância do aumento da tensão muscular para desencadear tal evento, dada a observância deste na condição excêntrico máximo. $\mathrm{O}$ desenho experimental foi bastante interessante, 
pois permitiu distinguir a resposta frente ao grau de tensão imposto ao tecido muscular.

BURRY, HAWKINS e SPANGENBURG (2007) também investigaram o efeito do tipo de ação muscular sobre atividade das vias. Contudo, estes autores optaram por um modelo experimental para avaliar se a manipulação do exercício de força influenciaria na fosforilação da $\mathrm{p} 70^{\mathrm{S} 6 \mathrm{~K}}$. Ratos foram submetidos a exercício agudo isométrico ou excêntrico utilizando o mesmo padrão de estimulação elétrica (a utilização de um aparato motorizado determinava o tipo de ação muscular). As amostras de tecido muscular foram obtidas seis horas após o término do procedimento experimental. A análise do torque produzido durante as ações excêntricas ou isométricas não mostraram diferenças, sugerindo que o stress mecânico imposto ao músculo foi similar. Entretanto, os autores observaram um aumento significante na fosforilação de $\mathrm{p} 70^{\mathrm{S} 6 \mathrm{~K}}$ para o grupo excêntrico em comparação ao isométrico. De maneira similar à ELIASSON et al. (2006), o tipo de ação muscular parece ter sido decisivo na resposta de fosforilação. Contudo, no estudo de BURRY, HAWKINS e SPANGENBURG (2007), a maior resposta ao estímulo excêntrico foi observada mesmo quando o exercício foi manipulado de forma a oferecer a mesma tensão sobre o músculo.

Para tentar entender este fenômeno, podemos observar o trabalho de SPANGENBURG e MCBRIDE (2006). Os autores buscaram determinar se a 
ativação dos canais de estiramento (SAC - stretch activated channels) pela ação excêntrica contribuiria para a ativação dos mecanismos de sinalização intracelular para hipertrofia. Através da utilização de modelo animal, os pesquisadores inibiram os SAC usando duas drogas distintas a fim de comparar o efeito de uma sessão aguda de exercícios excêntricos involuntários (induzidos por eletroestimulação). Nos animais submetidos ao exercício excêntrico, mas sem inibição dos SAC, a Akt mostrou-se significantemente mais ativa em relação ao grupo controle. Contudo, quando os animais foram submetidos ao exercício e tiveram a droga administrada, nenhuma alteração na Akt foi detectada. Neste experimento, os autores reportam que a fosforilação de GSK-3 $\beta$ (fator também associado com crescimento muscular) estava aumentada no grupo submetido ao exercício excêntrico sem inibição das SAC. Porém, quando a inibição estava presente, nenhuma alteração foi observada. De forma similar, o exercício excêntrico promoveu grande fosforilação da $\mathrm{p} 70^{\mathrm{S} 6 \mathrm{~K}}$. Entretanto, a inibição dos SAC diminuiu, mas não eliminou a magnitude do efeito do exercício excêntrico. Os autores sugerem que os SAC (que são ativados durante as ações excêntricas) são em parte responsáveis pela estimulação da atividade das quinases Akt e p70 ${ }^{\mathrm{S} 6 \mathrm{~K}}$, enfatizando a importância da tensão muscular durante a ação excêntrica no processo de hipertrofia. 


\subsection{Ações Excêntricas}

As ações musculares podem ser distinguidas em relação à suas funções e características mecânicas. São elas, as ações concêntrica, isométrica e excêntrica. A Tabela 1 apresenta as diferenças entre os três tipos de ações musculares.

Um fato interessante é que durante uma ação excêntrica o músculo é capaz de gerar maior tensão. Isso se deve à somatória entre as forças ativa e passiva geradas durante este tipo de ação muscular (JOUMAA et al., 2008). A força ativa dos sarcômeros é gerada pela interação entre os filamentos de actina e miosina, em um mecanismo denominado pontes cruzadas. Neste mecanismo os filamentos de actina deslizam sobre os de miosina, alterando o comprimento do sarcômero.

Alterações no comprimento do sarcômero provocam alterações também na sobreposição dos miofilamentos, o que pode afetar a produção de força uma vez que existe um comprimento ótimo para tal. Esse comprimento é próximo ao comprimento de repouso, ao redor de $2 \mu \mathrm{m}$ (Figura 2). Acima ou abaixo desse comprimento, a força ativa gerada pelo sarcômero diminui (GORDON, HUXLEY \& JULIAN, 1966). Durante ações musculares excêntricas o grau de sobreposição dos miofilamentos tende a diminuir conforme o músculo é alongado, o que reduz a possibilidade de formação das pontes cruzadas e dificulta a produção força ativa nesta situação. 
TABELA 1 - Características das três diferentes ações musculares. Adaptado de KNUTTGEN (1992).

\begin{tabular}{ccccc}
\hline $\begin{array}{c}\text { Tipo de } \\
\text { exercício }\end{array}$ & $\begin{array}{c}\text { Ação } \\
\text { Muscular }\end{array}$ & $\begin{array}{c}\text { Comprimento } \\
\text { Muscular }\end{array}$ & Função & $\begin{array}{c}\text { Trabalho } \\
\text { Mecânico } \\
\text { Externo }\end{array}$ \\
\hline & Concêntrica & diminui & aceleração & positivo \\
Dinâmico & Excêntrica & aumenta & desaceleração & $\begin{array}{c}\text { negativo } \\
(\mathrm{W}=\mathrm{f}(+\mathrm{d}))\end{array}$ \\
& & & & zero \\
& & & fixação & não muda \\
Estático & Isométrica & não muda) & \\
\hline W=trabalho, f=força, d=distância & & &
\end{tabular}

No entanto, a tensão passiva, a qual oferece resistência ao alongamento dos sarcômeros, aumenta enquanto o músculo é alongado, contribuindo para a geração de força durante ações excêntricas. Tal força é exercida pelos tendões e pelos elementos elásticos encontrados nas cabeças de miosina e nas proteínas que ancoram e estabilizam os miofilamentos no sarcômero como a titina e a desmina (HERZOG, 1998). 


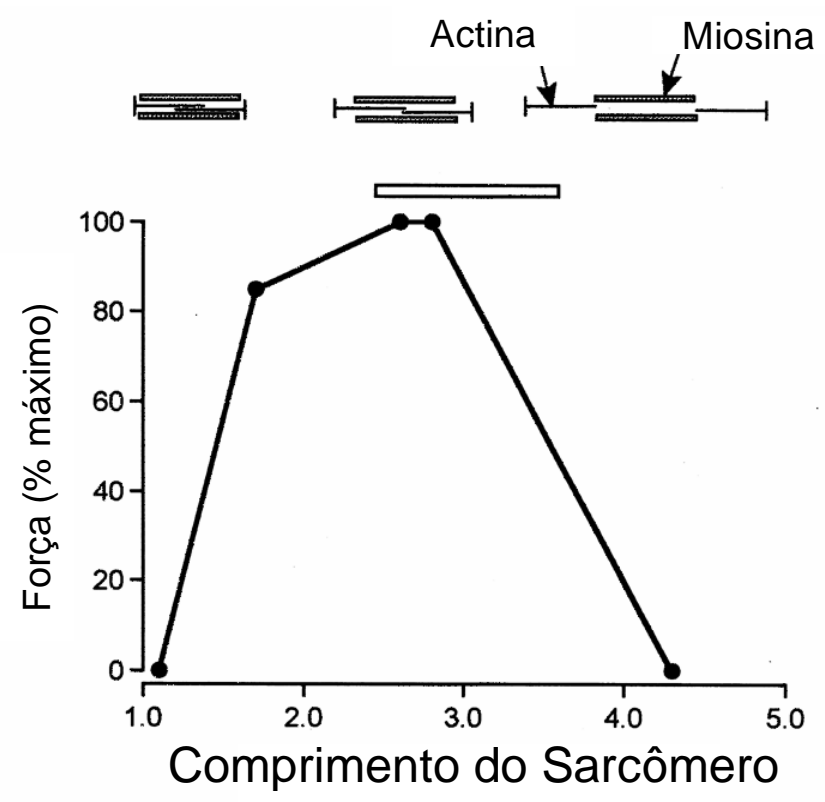

FIGURA 2 - Curva força x comprimento do sarcômero. Adaptado de ENOKA (2002).

A velocidade de contração também exerce influência sobre a regulação da força, afetando a possibilidade de formação de pontes cruzadas durante a contração muscular (EDMAN, 1992). Segundo o mesmo autor, o músculo tem uma capacidade inerente de ajustar a produção de força ativa à sobrecarga durante uma ação concêntrica. Portanto, quando a sobrecarga é alta, o músculo aumenta a força ativa para igualar a demanda através da redução da velocidade de encurtamento. Estudos bastante antigos já verificavam este fenômeno. Segundo EDMAN (1992), Fenn e Marsh, em 1935, foram os primeiros a demonstrar a relação entre força e velocidade, e Hill, em 1938, aprimorou o modelo e enfatizou a importância deste parâmetro em estudos sobre a função. 
Por outro lado, EDMAN (1988) descreveu o comportamento da força muscular em relação a velocidades negativas (para ações excêntricas). Nessa nova curva, quando a velocidade tornava-se negativa, o músculo era alongado ativamente em uma ação excêntrica e a força superava a força máxima concêntrica. Contudo, a força muscular produzida durante a ação excêntrica mantinha-se relativamente constante com a variação da velocidade (KOMI, 1973) (Figura 3).

Outra particularidade das ações excêntricas está relacionada ao seu padrão de ativação neural. A atividade eletromiográfica durante ações excêntricas é menor para mesma carga absoluta e relativa quando comparada a ações concêntricas e isométricas, indicando menor ativação da musculatura (AAGAARD, SIMONSEN, ANDERSEN, MAGNUSSON, HALKJAERKRISTENSEN \& DYHRE-POULSEN, 2000; AMIRIDIS, MARTIN, MORLON, MARTIN, COMETTI, POUSSON \& VAN HOECKE, 1996). De forma interessante, esta menor ativação muscular observada nas ações excêntricas, pode resultar em maior sobrecarga mecânica sobre as fibras ativas, consistindo então em um estímulo tensional mais intenso. 


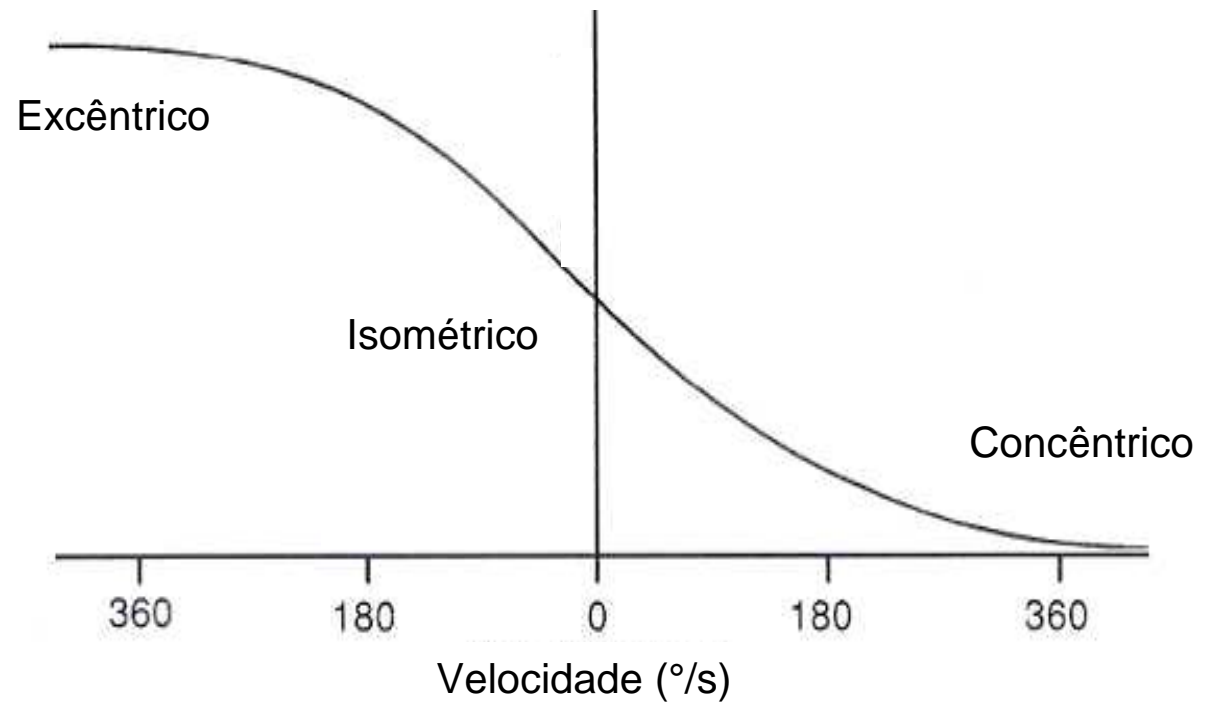

FIGURA 3 - Curva força x velocidade de contração. Adaptado de ENOKA (2002).

Adicionalmente, alguns autores (HOWELL, FUGLEVAND, WALSH \& BIGLAND-RITCHIE, 1995; NARDONE, ROMANO \& SCHIEPPATI, 1989; NARDONE \& SCHIEPPATI, 1988; WARREN, HERMANN, INGALLS, MASSELLI \& ARMSTRONG, 2000) discutem que o recrutamento de unidades motoras durante este tipo de ação muscular não segue o princípio do tamanho, o qual parte da premissa que as unidades motoras menores, de menor limiar de ativação e com menor capacidade de produzir força são recrutadas em primeiro lugar. Com a necessidade de aumentar a geração de força, unidades motoras maiores, com limiares de excitabilidade mais altos e com maior capacidade de produção de força são recrutadas posteriormente. De forma alternativa, o 
recrutamento aconteceria na ordem reversa, e as unidades motoras maiores seriam seletivamente acionadas (NARDONE, ROMANO \& SCHIEPPATI, 1989).

\subsubsection{Modulação das ações excêntricas e ganhos de força e hipertrofia}

A literatura parece de certa forma conclusiva no que diz respeito ao maior efeito das ações excêntricas em comparação às concêntricas e isométricas na promoção da hipertrofia muscular e ganhos de força (HIGBIE et al., 1996; HORTOBAGYI et al., 1996; SEGER, ARVIDSSON \& THORSTENSSON, 1998).

Já discutimos anteriormente o papel do tipo de ação muscular na ativação das vias de sinalização celular para a síntese protéica. Neste momento, discutiremos o efeito da modulação da velocidade de execução das ações excêntricas e os ganhos de força e hipertrofia.

Em um estudo interessante, PADDON-JONES et al. (2001) submeteram sujeitos a 10 semanas (3x/semana) de treinamento de força excêntrico com velocidade baixa $(30 \% \mathrm{~s}, \mathrm{n}=6)$, ou alta $(180 \% \mathrm{~s}, \mathrm{n}=7)$. Foram conduzidas análises de torque isométrico, concêntrico e excêntrico (os dois últimos em velocidades de $30 \%$ e $180 \%$ s) nos momentos pré-treinamento, cinco e 10 semanas após o período experimental. Adicionalmente, os autores realizaram biópsias pré e póstreinamento para análise da composição do músculo bíceps braquial. De forma 
inespecífica, o treinamento excêntrico de alta velocidade mostrou maiores ganhos para os torques excêntricos em velocidade alta e baixa. Além disso, o mesmo modelo de treino se mostrou mais eficiente para o ganho de força concêntrico em alta velocidade assim como para o torque isométrico. Os autores creditaram seus achados a um possível efeito de overtraining no grupo velocidade baixa, uma vez que o tempo sob tensão era maior para este grupo. Os autores encontraram também, um aumento no percentual de fibras do tipo $\operatorname{IIb}(7,1 \%)$ e diminuição no percentual de fibras to tipo I $(14,7 \%)$ no grupo que treinou com alta velocidade. Não foram encontradas variações no tipo de fibra para o grupo que utilizou AE de velocidade baixa. Infelizmente as análises não contemplaram o estudo da área da secção transversa, deixando uma lacuna para a resposta hipertrófica em decorrência deste modelo de treinamento.

Mais tarde, FARTHING e CHILIBECK (2003) manipularam de maneira similar a velocidade dos movimentos, contudo, estes pesquisadores optaram pela inclusão de ações concêntricas, usando um modelo onde os sujeitos eram divididos em grupos baixa $\left(30^{\circ} / \mathrm{s}\right)$ ou alta $\left(180^{\circ} / \mathrm{s}\right)$ velocidade, e realizavam treinamento excêntrico por oito semanas em um dos braços, seguido de mais oito semanas de treinamento concêntrico no braço contralateral. De forma geral, o treinamento excêntrico veloz promoveu ganhos significantemente maiores de hipertrofia em comparação ao concêntrico veloz e concêntrico lento (13\%, 5,3\% e 
$2,6 \%$, respectivamente), enquanto o treinamento excêntrico lento foi melhor apenas que o grupo controle $(7,8 \%)$. O braço que treinou de forma excêntrica com alta velocidade mostrou mais hipertrofia que todas as outras condições, exceto o excêntrico lento. Segundo os autores, o maior efeito hipertrófico observado poderia estar associado à maior ocorrência de dano muscular e infiltração de células satélite com conseqüente maior resposta reparadora. Em relação aos ganhos de força, o treinamento excêntrico em alta velocidade resultou em maiores ganhos de torque excêntrico nas duas velocidades testadas (30\% e 180\%) $(16 \%$ dados agrupados entre as velocidades) em comparação ao excêntrico e concêntrico lentos (6\% e 5\%, respectivamente). Já para o torque concêntrico, o grupo excêntrico veloz mostrou maiores aumentos (22,5\%) que todas as condições, exceto excêntrico lento $(17,5 \%)$.

SHEPSTONE et al. (2005) também investigaram o efeito da manipulação da velocidade das ações excêntricas nos ganhos de hipertrofia e força muscular. Contudo, eles utilizaram as velocidades de $20 \%$ e $210 \%$ em dois estudos. No primeiro estudo os autores tentaram verificar o efeito da manipulação da velocidade sobre a hipertrofia muscular. Para tal, foram realizadas oito semanas de treinamento $(3 \mathrm{x} /$ semana) onde os sujeitos deveriam exercitar um braço com alta e o braço contralateral com baixa velocidade. Biópsias pré e pós período de treinamento foram obtidas no músculo bíceps braquial para avaliação da área da 
secção transversa (AST) por tipo de fibra. Foram também realizadas avaliações de torque isométrico e concêntrico/excêntrico em cinco diferentes velocidades $\left(20^{\circ}, 60^{\circ}, 120^{\circ}, 180^{\circ}\right.$ e $\left.210^{\circ} / \mathrm{s}\right)$. Os autores observaram que o treinamento excêntrico veloz $(210 \%$ s) resultou em maiores ganhos de torque em todas as velocidades avaliadas em comparação com o treinamento de baixa velocidade $(20 \%)$. Houve uma tendência a maior AST total para o grupo veloz $(\mathrm{p}=0.06)$, porém quando analisados os diferentes tipos de fibra isoladamente, a AST das fibras do tipo IIA e IIX foi significantemente maior para o grupo excêntrico veloz. Contudo, não houve diferença para AST nas fibras do tipo I. A segunda parte do estudo teve como objetivo verificar a influência aguda da manipulação da velocidade sobre um indicador de remodelação protéica (análise do desarranjo das linhas Z). Para tal, um grupo de sujeitos foi submetido a biópsias pré e pós procedimento experimental, o qual consistiu na realização de 3 séries de 10 movimentos excêntricos rápidos $\left(210^{\circ} / \mathrm{s}\right)$ em um braço ou lentos $\left(20^{\circ} / \mathrm{s}\right)$ no braço contralateral. Os pesquisadores observaram que o desarranjo de linhas $\mathrm{Z}$ foi maior após o exercício veloz em comparação ao lento indicando maior remodelação protéica após o treinamento com altas velocidades excêntricas. É importante destacar a diferenciação que os autores fazem entre desarranjo das linhas $\mathrm{Z}$ e o dano muscular com ruptura dos sarcômeros, uma vez que muitos estudos creditam o efeito hipertrófico acentuado das ações excêntricas ao maior grau de 
lesão celular gerado por estas em comparação às ações isométricas ou concêntricas (FARTHING \& CHILIBECK，2003; MACDOUGALL，1986; PADDON-JONES et al., 2001).

Dando suporte a estes dados, MORGAN e PARTRIDGE (2003) associam o dano muscular à ativação de células satélite e à liberação de fatores de crescimento que auxiliam no processo de síntese protéica. Tal dano muscular poderia ser ocasionado quando os sarcômeros são alongados ativamente (AE). Em tal situação, a sobreposição dos miofilamentos diminui, reduzindo a possibilidade de formação das pontes cruzadas. Dentre todos os sarcômeros ativos, existem alguns que são mais fracos que outros, sendo então submetidos a maiores comprimentos de alongamento, provocando ainda maior diminuição na sobreposição dos miofilamentos (MORGAN, 1990; MORGAN \& PROSKE, 2004). Após o término de uma AE, os miofilamentos voltariam a se sobrepor em apenas em alguns sarcômeros. Portanto, nos sarcômeros onde a sobreposição de actina e miosina não fosse restabelecida, não haveria suporte dos componentes contráteis à tensão imposta na próxima ação muscular, sobrecarregando assim, os elementos elásticos destes sarcômeros e aumentando a incidência do seu rompimento (MORGAN, 1990; MORGAN \& PROSKE, 2004). Portanto, o dano parece depender da tensão imposta aos elementos elásticos. 
Tendo em vista os melhores resultados das AE velozes em produzir ganhos em hipertrofia, e a possível influência do dano muscular na hipertrofia, alguns pesquisadores verificaram o efeito da velocidade das AE sobre o dano muscular.

LYNCH e FAULKNER (1998) investigaram o efeito da velocidade de alongamento em fibras isoladas ativas. Os autores submeteram cada fibra do músculo extensor digital longo de animais à um estímulo de alongamento em magnitudes (5, 10 e $20 \%$ do comprimento da fibra - cf) e velocidades distintas $(0,5,1$ e 2 cf/seg). Não foram encontradas diferenças no déficit de força após esse procedimento. Uma vez que tem sido sugerido que diminuição da força muscular é o melhor indicativo indireto de dano muscular (WARREN, LOWE \& ARMSTRONG, 1999) parece razoável concluir que os resultados observados indicam que o dano não foi dependente da velocidade do alongamento in vitro.

CHAPMAN, NEWTON, SACCO e NOSAKA (2006) também investigaram o efeito da velocidade no grau de dano induzido. Os autores testaram duas velocidades (30 e $210 \%$ ), contudo, para normalizar o tempo sob tensão para cada grupo (120 segundos), o número de repetições foi manipulado. Assim, o grupo veloz desempenhou um número significantemente maior de repetições do que o grupo que realizou o exercício na velocidade baixa (210 e 30 repetições, respectivamente). Através da mensuração de marcadores indiretos de dano muscular, os autores observaram um maior grau de dano quando a velocidade alta 
foi utilizada. Porém, MCCULLY e FAULKNER, (1986) reportam que o número de ações musculares pode afetar o grau de dano muscular. Assim, a diferença encontrada entre os grupos pode ser devido ao número de ações realizadas e não à velocidade da ação.

Em outro estudo recente, CHAPMAN et al. (2008) dividiram 16 homens em dois grupos. Um grupo realizou 30, e o outro 210 movimentos excêntricos com os músculos flexores do cotovelo. Contudo, ambos os braços de cada sujeito eram submetidos ao exercício. De forma aleatória, o braço dominante ou não dominante foi designado à velocidade baixa $(30 \%)$ ou alta $(210 \%$ s) de exercício. Os resultados indicaram que quando um número menor de movimentos foi utilizado (30 repetições), o efeito da velocidade sobre a magnitude do dano muscular foi mínimo. Entretanto, quando um maior número de repetições (210 movimentos) foi avaliado, os resultados em direção ao maior dano em decorrência da maior velocidade de execução foram mais evidentes (diminuição da força isométrica, da força concêntrica, da amplitude de movimento e do aumento da concentração sérica de CK).

Adicionalmente, a realização de uma única sessão de treinamento com ações excêntricas parece propiciar um efeito profilático na realização das sessões subseqüentes. Quando uma sessão de exercícios excêntricos é repetida até seis meses após a sessão inicial a quantidade de dano induzida pelo treinamento é 
menor (NOSAKA et al., 2001). A existência desse efeito indica a presença de alguma adaptação na estrutura do citoesqueleto que "protege" a fibra muscular, diminuindo a ocorrência de danos provocados pela repetição da sessão de exercícios excêntricos. Todavia, apesar de haver a diminuição do dano muscular, ele ainda continua ocorrendo após a segunda sessão com ações excêntricas, como indica a análise da concentração de creatina quinase, da amplitude de movimento, da percepção da dor muscular tardia e da força muscular (NOSAKA \& CLARKSON, 1995).

Um estudo prévio (dados não publicados) realizado em nosso laboratório corrobora estes dados. Não foram encontradas diferenças no grau de dano muscular (observado através de marcadores indiretos) quando 30 movimentos excêntricos eram desempenhados a $60 \%$ ou $180 \%$ s. Da mesma maneira, não houve mais indícios de ocorrência de dano celular após a realização da terceira sessão de exercícios excêntricos em ambas as velocidades (efeito da carga repetida).

Estes dados sugerem que embora o dano muscular promova a ativação de células satélite, e estas tenham ligação com o crescimento muscular, este mecanismo não parece ser plausível para explicar o fenômeno em longo prazo devido ao efeito da carga repetida e conseqüente diminuição do dano muscular. 
Ainda segundo CHAPMAN et al. (2008), a execução de ações excêntricas em maior velocidade poderia resultar em maior stress mecânico do que as ações excêntricas mais lentas. Tal fenômeno se daria pelo fato da diminuição da interação entre os miofilamentos com o aumento da velocidade de alongamento, diminuindo então, a participação da força ativa no output final. Conforme discutido anteriormente, parece não haver diferença significante no torque excêntrico voluntário produzido em diferentes velocidades (KOMI, 1973), portanto parece razoável assumir que o grau de stress mecânico sobre a fibra muscular é similar entre velocidades baixas e altas. Novamente, uma vez que teríamos a diminuição da participação da força ativa, os elementos passivos arcariam com maior produção de força, resultando no maior stress mecânico.

Considerando as proposições acima, é possível especular que durante a modulação do tipo e da velocidade da ação (ações excêntricas velozes), o consequente aumento do stress mecânico seria então o responsável pelo maior efeito hipertrófico. Tal fenômeno pode, portanto, exercer influência positiva sobre a ativação das vias de hipertrofia, favorecendo o aumento da massa muscular. 


\section{MATERIAIS E MÉTODOS}

\subsection{Amostra}

Vinte e quatro indivíduos do sexo masculino, praticantes de atividade física, porém não envolvidos em treinamento de força havia pelo menos seis meses, se voluntariaram para participar como sujeitos do estudo. Todos eram saudáveis e não possuíam histórico de lesões no joelho. O grau de participação em atividades físicas foi determinado através do preenchimento de um questionário (anexo 1). Antes da sessão experimental, quatro sujeitos desistiram da participação por razões pessoais. Os sujeitos foram informados dos procedimentos, riscos e objetivos da pesquisa e assinaram um termo de consentimento informado e esclarecido. Todos os procedimentos foram aprovados pelo Comitê de Ética em Pesquisa da Escola de Educação Física e Esporte da Universidade de São Paulo.

Para divisão dos grupos, os sujeitos realizaram um teste de força isométrica máxima dos músculos extensores do joelho. Após este, eles foram classificados em quartis e os sujeitos de cada quartil foram aleatoriamente alocados nos grupos a seguir:

- Exercício de força excêntrico de baixa velocidade (20\%s) (EXC20)

- Exercício de força excêntrico de alta velocidade (210\%) (EXC210) 
As velocidades foram escolhidas baseadas no estudo de SHEPSTONE et al. (2005) e as características dos indivíduos componentes de cada grupo são apresentadas na Tabela 2.

TABELA 2 - Características dos indivíduos (média \pm DP).

\begin{tabular}{llll}
\hline & Massa corporal $(\mathrm{kg})$ & Estatura $(\mathrm{m})$ & Idade (anos) \\
\hline Exc20 & $77,18 \pm 10,50$ & $1,76 \pm 0,06$ & $25,36 \pm 5,04$ \\
Exc210 & $76,30 \pm 9,60$ & $1,77 \pm 0,03$ & $26,40 \pm 4,27$ \\
\hline
\end{tabular}

\subsection{Procedimentos Experimentais}

O estudo foi conduzido em dois laboratórios diferentes. Numa primeira etapa foram feitas as coletas de tecido muscular através da técnica de biópsia, para as análises pré intervenção experimental. Para tal, os sujeitos compareceram ao Laboratório de Adaptações ao Treinamento de Força da EEFE-USP durante o período da manhã. A biópsia (descrita abaixo) foi feita na perna não dominante após um período de 8 horas de jejum overnight.

Aproximadamente 3-4 semanas após a coleta inicial, deu-se a intervenção experimental. Os sujeitos reportaram-se Centro de Estudos em Psicobiologia e Exercício no Instituto do Sono da Universidade Federal de São Paulo (CEPEUNIFESP) onde o restante do experimento foi realizado. Novamente, os 
procedimentos aconteceram pela manhã e todos os indivíduos receberam as mesmas orientações sobre a alimentação prévia ao experimento.

O procedimento consistiu na realização de séries múltiplas de exercício excêntrico com a perna dominante, em diferentes velocidades e será descrito em detalhes em sessão a seguir. Ao término do exercício excêntrico, os sujeitos foram imediatamente submetidos à nova coleta de tecido muscular, desta vez na perna exercitada. Uma nova amostra, a partir da mesma incisão, foi obtida após um intervalo de 2 horas do término do exercício. A figura 4 ilustra a temporalidade dos eventos ao longo do experimento.

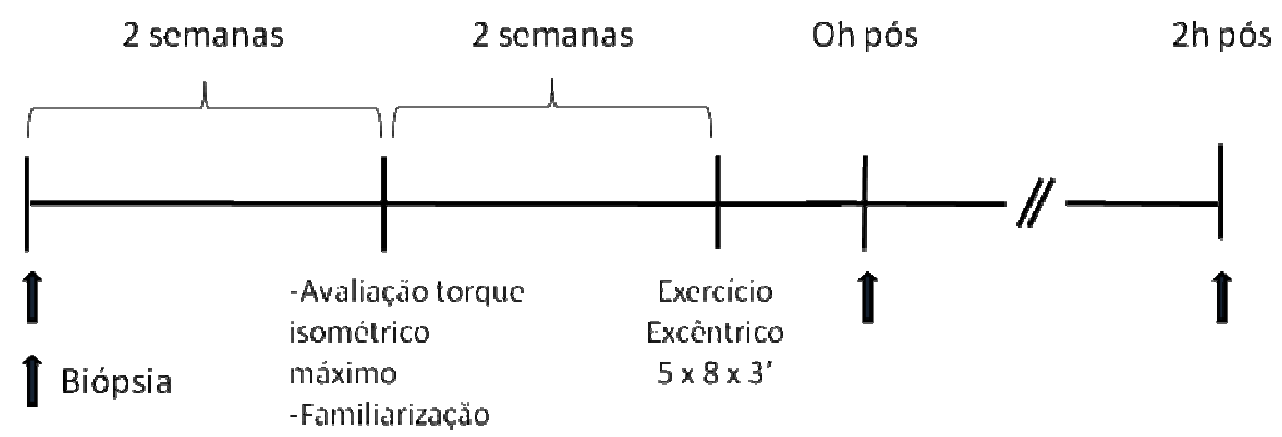

FIGURA 4 - Linha temporal dos procedimentos experimentais.

\subsection{Monitoração do padrão alimentar dos sujeitos}

Todos os sujeitos foram questionados quanto o uso de suplementos alimentares e drogas que pudessem afetar os resultados do estudo. Nenhum 
participante fazia uso de qualquer substância que pudesse alterar os resultados, e todos foram solicitados a preencher um recordatório alimentar referente à refeição que precedia (jantar) ambas as sessões experimentais. Os dados foram tabulados utilizando software específico (Virtual Nutri - versão 1.0, Universidade de São Paulo, Brasil) e os sujeitos foram instruídos a repetirem o mesmo padrão alimentar (referente à primeira sessão) na visita subsequente. A análise dos dados de ingestão alimentar (jantar) prévios à coleta controle e à sessão experimental, não revelou diferenças significantes para os grupos entre os tempos (Tabela 3).

TABELA 3 - Ingestão nutricional pré-sessão controle (CTL) e sessão experimental (EXP). Os dados são apresentados em valores percentuais como média ( \pm desvio padrão).

\begin{tabular}{|c|c|c|c|c|c|c|c|c|}
\hline & \multicolumn{4}{|c|}{ EXC 20} & \multicolumn{4}{|c|}{ EXC 210} \\
\hline & CHO & LIP & PROT & KCAL & CHO & LIP & PROT & KCAL \\
\hline \multirow[t]{2}{*}{ CTL } & 56,82 & 30,06 & 13,12 & 550,30 & 63,78 & 24,42 & 11,80 & 522,10 \\
\hline & $(7,909)$ & $(10,234)$ & $(2,189)$ & $(74,795)$ & $(8,376)$ & $(7,380)$ & $(2,705)$ & $(36,898)$ \\
\hline \multirow[t]{2}{*}{ EXP } & 61,32 & 27,18 & 11,50 & 535,90 & 60,80 & 25,66 & 13,54 & 528,31 \\
\hline & $(6,728)$ & $(6,515)$ & $(1,797)$ & $(32,982)$ & $(9,549)$ & $(8,108)$ & $(3,562)$ & $(40,541)$ \\
\hline
\end{tabular}




\subsection{Biópsia muscular}

Para obtenção das amostras para determinação da expressão gênica de MGF e mTOR e quantificação das proteínas p70 ${ }^{\mathrm{S} 6 \mathrm{~K}}$ e Akt (total e fosforilada), foram realizadas biópsias subcutâneas da porção medial do músculo vasto lateral. Antes da extração do tecido, a área foi tricotomizada e limpa com antisséptico. Uma pequena área, sobre a região selecionada, foi anestesiada com xilocaína à $2 \%$, injetada de forma subcutânea no local. Após a anestesia, uma pequena incisão, de aproximadamente $0,5 \mathrm{~cm}$ de largura, foi feita até a fáscia do músculo utilizando bisturi cirúrgico. A agulha de biópsia foi então introduzida no músculo numa profundidade aproximada de três centímetros para obtenção da amostra de tecido muscular ( 70 a $100 \mathrm{mg}$ ). Após a retirada do tecido, a incisão foi fechada e coberta por bandagens.

Este procedimento foi realizado em três oportunidades. A primeira foi realizada num período de aproximadamente 3-4 semanas antes do início da realização da intervenção experimental (perna não dominante). As duas outras amostras foram obtidas imediatamente e 2 horas após o término da mesma, ambas na perna dominante, que realizou o exercício excêntrico. As amostras pós intervenção foram obtidas tendo como referência a cicatriz da amostra inicial. A amostra final (2 horas pós intervenção) foi retirada a partir da mesma incisão da biópsia imediatamente após. 
As amostras foram limpas (retirada de sangue e excesso de tecido conectivo) e divididas em duas alíquotas. Uma delas foi processada para a extração das proteínas totais conforme descrição em outro tópico, e a outra foi imediatamente congelada em nitrogênio líquido e conservada à $-70^{\circ} \mathrm{C}$ até o momento das análises.

\subsection{Torque isométrico máximo e sessão de familiarização}

O torque isométrico máximo foi medido em dinamômetro isocinético (Biodex System 3, Biodex Medical Systems, NY, EUA) aproximadamente duas semanas após o procedimento de biópsia inicial e duas semanas antes da realização da intervenção experimental. Os valores foram utilizados no ranqueamento e aleatorização dos sujeitos.

Para a mensuração do torque isométrico, os sujeitos sentaram-se na cadeira do dinamômetro isocinético, assumindo um ângulo de $90^{\circ}$ na articulação do quadril. O joelho do membro dominante foi posicionado próximo ao braço de alavanca do aparelho, e o epicôndilo femoral (eixo de rotação anatômico) foi alinhado com o eixo de rotação do braço de alavanca do aparelho. O ponto de apoio do braço de alavanca do aparelho foi situado à $1 \mathrm{~cm}$ proximal do maléolo medial dos sujeitos. Adicionalmente, os sujeitos foram fixados por cintas ao aparelho, evitando a alteração de sua posição durante a execução do movimento, 
prevenindo também, contribuições de outros segmentos corporais na realização do exercício.

O ângulo de mensuração utilizado foi de $60^{\circ}$ a partir da extensão completa do joelho (assumindo $0^{\circ}$ na horizontal). Os sujeitos tiveram cinco segundos para atingir o pico de torque e em todas as tentativas os sujeitos receberam instrução para executar um esforço máximo e encorajamento verbal foi fornecido. Os indivíduos realizaram três tentativas, com intervalos de três minutos entre elas. O valor de pico de torque foi obtido em cada uma das tentativas para análise futura.

Na mesma sessão da avaliação do torque isométrico, os sujeitos foram submetidos a uma sessão de familiarização a intervenção experimental (exercícios excêntricos desempenhados no dinamômetro isocinético). Para tal, os sujeitos foram posicionados no aparelho (conforme descrição acima) e foram submetidos a duas séries de exercício excêntrico a uma velocidade de $120 \%$ s (inespecífica a ambos os grupos). A escolha desta velocidade para a familiarização visou ambientar os sujeitos ao procedimento e ao aparelho, evitando qualquer efeito de adaptação velocidade-específico. A sessão de familiarização foi realizada na perna não dominante a fim de evitar quaisquer efeitos de ativação das vias de sinalização da hipertrofia. 


\subsection{Intervenção experimental}

A intervenção experimental consistiu na realização de 5 séries de 8 movimentos excêntricos em uma das velocidades estipuladas com intervalo de três minutos entre séries.

Foi utilizado o dinamômetro isocinético (Biodex System 3, Biodex Medical Systems, NY, EUA) e os sujeitos assumiram a mesma posição utilizada durante o teste isométrico máximo. Os indivíduos partiram da posição de extensão do joelho $\left(0^{\circ}\right)$ até a flexão à $90^{\circ}$ (posição final), realizando assim, uma ação muscular excêntrica na velocidade correspondente ao seu grupo experimental. $\mathrm{O}$ aparelho retornou de forma passiva à posição inicial na velocidade de $20 \%$ seg totalizando um período de 4,5 segundos de intervalo entre cada repetição. Imediatamente e duas horas após o término do exercício excêntrico, os sujeitos foram submetidos às biópsias para obtenção das amostras de tecido muscular conforme descrito anteriormente.

\subsection{Quantificação das proteínas Akt e p70 ${ }^{\mathrm{S} 6 \mathrm{~K}}$}

Os reagentes e os aparelhos para eletroforese em gel de sódio dodecil sulfato de poliacrilamida (SDS-PAGE) utilizados foram da marca Bio-Rad (BioRad, Richmond, CA, EUA). Metano hidroximetilamina (TRIS), fenilmetilsulfonilfluoreto (PSMF), aprotinina, ditiotreitol (DTT), DHEA, 
albumina, colagenase tipo V e poli-lisina foram fornecidos pela Sigma Chemical Co. (Sigma Chemical Co., St. Louis, MO, EUA) e insulina regular pela Lilly (Lilly, São Paulo, SP, Brasil). A membrana de nitrocelulose, ECL e os kits para detecção por quimioluminescência foram fornecidos pela Amersham (Amersham Biosciences, Piscataway, NJ, EUA). D-glicose anidra e PEG (polietileno glicol + tampão borato) foram fornecidos pela Labsynth (Labsynth, Diadema, SP, Brasil). Os anticorpos anti-Akt, anti- ${ }_{\mathrm{p}} \mathrm{Akt}$, anti-S6k $\left(\mathrm{p}^{70}\right)$ e anti- $\mathrm{p} 6 \mathrm{k}\left(\mathrm{p}^{70}\right)$ foram adquiridos junto à Upstate Biotechnologies (Upstate Biotechnology, Charlottesville, VA, EUA) e Santa Cruz Biotechnology (Santa Cruz Biotechnology, Santa Cruz, CA, EUA) respectivamente.

\subsubsection{Extração das proteínas totais dos músculos esqueléticos}

Foi feita a extração de proteínas totais das amostras obtidas. Os músculos foram homogeneizados com polytron em $1,5 \mathrm{ml}$ de tampão de extração constituído de Triton-X 100 1\%, Tris (pH 7,4) 100 mM, pirofosfato de sódio 100 mM, fluoreto de sódio $100 \mathrm{mM}$, EDTA $10 \mathrm{mM}$, ortovanadato de sódio $10 \mathrm{mM}$, PMSF $2 \mathrm{mM}$ e aprotinina $0,01 \mathrm{mg} / \mathrm{ml}$. Os extratos foram centrifugados a 12000 rpm a $4{ }^{\circ} \mathrm{C}$ por 40 minutos para a remoção do material insolúvel. Após centrifugação, foi realizada a normalização da concentração de proteínas para todas as amostras utilizando reagente Bradford (Bio-Rad - Richmond, CA, EUA) 
em espectrofotômetro $\mu$ Quant (Bio Tek Instruments - Winoosk, VT, EUA). Em seguida, os sobrenadantes foram tratados com tampão de Laemmli, acrescido de DTT $200 \mathrm{mM}$, na proporção de 4:1 (V:V), aquecidos em água fervente por 5 minutos, e de 50 a $100 \mu \mathrm{g}$ de proteína total foram submetidas à eletroforese em gel de poliacrilamida (SDS-PAGE) no aparelho de mini gel. Em cada gel foi utilizado marcador de peso molecular pré-corado com valores estabelecidos como padrão (Bio-Rad, Richmond, CA, EUA).

\subsubsection{Análise protéica por immunoblotting}

A transferência das proteínas separadas no gel foi feita eletricamente para uma membrana de nitrocelulose, através da aplicação de uma corrente de $120 \mathrm{~V}$ por 2 horas, como descrito por TOWBIN, STAEHELIN e GORDON (1979). Porém, no tampão foi acrescido sódio dodecil sulfato (SDS) $0,1 \%$ para melhorar a eluição de proteínas de alto peso molecular. A ligação inespecífica de proteínas nas membranas de nitrocelulose foi diminuída pela incubação destas com uma solução bloqueadora (leite desnatado Molico 5\%, Tris $10 \mathrm{mM}, \mathrm{NaCl} 150 \mathrm{mM}$ e Tween 20 0,02\%) em temperatura ambiente por 2 horas e lavadas com esta solução sem leite por 30 minutos. As membranas foram então incubadas com anticorpos específicos em solução bloqueadora (com 3\% de BSA) durante a noite a $4^{\circ} \mathrm{C}$ e lavadas com a mesma solução sem leite ou BSA, por 30 minutos. Em 
seguida, as membranas foram incubadas com anticorpo conjugado com peroxidase por 1 hora em temperatura ambiente, lavadas com a solução sem leite ou BSA e usada solução para detecção por quimioluminescência como descrito no protocolo de cada anticorpo. A intensidade das bandas nas auto-radiografias reveladas foi determinada através da leitura por densitometria óptica das imagens escaneadas utilizando um scanner (HP PSC 1510). O programa Scion Image (Scion Corporation - Frederick, MD, EUA) converteu os valores de densidade em unidades arbitrárias, quantificando as proteínas de interesse.

\subsection{Determinação da expressão gênica de MGF e mTOR}

A determinação da expressão gênica de MGF foi feita a partir do método de detecção em tempo real.

\subsubsection{Extração do RNA}

A extração do RNA total do tecido foi realizada com o reagente TRIZOL (Gibco Products/Invitrogen Corporation - Carlsbad, CA, EUA). Para confirmação da qualidade do processo de extração foi utilizada a relação RNA/DNA, determinada no espectrofotômetro, sendo somente utilizadas amostras que atingiram o intervalo de 1,6 a 2,0 (U.A.). A integridade do RNA 
também foi verificada em gel de agarose $1 \%$, não denaturante, corado com brometo de etídeo.

\subsubsection{RT-PCR}

O método de RT-PCR (Reverse Transcriptase - Polymerase Chain Reaction) foi adotado para quantificação da concentração de RNAm para as proteínas estudadas.

Uma pequena alíquota $(5 \mu \mathrm{l})$ do RNA total foi submetida à técnica RTPCR. Para isto, foi empregada a enzima trancriptase reversa SuperScript ${ }^{\mathrm{TM}}$ RNAse $\mathrm{H}^{-}$(Gibco Products/Invitrogen Corporation - Carlsbad, CA, EUA) em $20 \mu \mathrm{l}$ de reação contendo $4 \mu \mathrm{l}$ do tampão fornecido pelo fabricante, $0,8 \mathrm{mM}$ dNTPs, $1 \mathrm{mM} \mathrm{MgCl} 2,0,02 \mu \mathrm{g} / \mu$ l oligo-desoxitimidina primer (iniciador), $4 \mathrm{mM}$ DTT. A reação foi realizada em termociclador de DNA (Perkin Elmer GeneAMP PCR System 2400, Norwalk, CT, EUA).

Para amplificação do cDNA das proteínas de interesse foram utilizados iniciadores (primers). O produto da reação foi analisado por eletroforese em gel de agarose $1,0 \%$ corado com brometo de etídeo. O gel foi fotografado pelo sistema de aquisição de imagem Kodak Digital Science Eletrophoresis Documentation and Analyses System (Eastman Kodak Company, NY, USA). 
Posteriormente, a densitometria das bandas foi realizada no Kodak Digital Science 1D Image Analyses Software (Eastman Kodak Company, NY, USA).

\subsubsection{Método de detecção da expressão gênica em tempo real}

Após a obtenção do cDNA, as diferentes frações das RTs foram utilizadas na amplificação em cadeia por polimerase (PCR) em um equipamento que monitora a amplificação em tempo real (GeneAmp 5700 -Applied Biosystems Foster City, CA, EUA). Neste equipamento foi determinado o início da fase de amplificação exponencial (CT, cycle threshold), que foi utilizado como dado para a análise da expressão gênica dos genes de interesse.

No sistema de amplificação real time, as fases de anelamento, extensão e denaturação ocorrem durante os ciclos de maneira similar quando da utilização do termociclador convencional. A diferença é que a amplificação da seqüência alvo é detectada em tempo real pela emissão de fluoroforo, que ocorre quando há formação de dupla fita na região codificada pelo par de iniciadores. A quantificação relativa da amplificação é feita pela fluorescência detectada pela unidade óptica do aparelho. Neste sistema, em um gráfico hipotético em que a ordenada corresponderia ao número de cópias e a abscissa ao número de ciclos, o resultado teórico esperado é uma curva do tipo sigmóide. O ideal no PCR tradicional é efetuar uma reação em que o número de ciclos escolhido se encontre 
dentro do trecho linear da curva, evitando-se assim os extremos assintóticos. Pelas características do PCR real time é possível determinar este perfil de amplificação, o que representa uma das vantagens metodológicas. O ponto na abscissa correspondente ao início do trecho linear é chamado de CT e este valor é utilizado para a comparação relativa da expressão gênica: quanto menor o CT, mais expressa é determinada mensagem.

Os iniciadores (primers) utilizados para a amplificação dos genes de interesse (IGF1 e MGF) foram desenhados com o software Primer Express (Applied Biosystems - Foster City, CA, EUA).

\subsection{Análise estatística}

Os dados foram testados quanto a normalidade e são apresentados com estatística descritiva (média \pm desvio padrão). Para comparar o efeito das diferentes velocidades de exercício excêntrico nas variáveis dependentes quantificação de proteínas e expressões gênicas foram utilizados modelos mistos tendo tempo (3 níveis) e velocidade (2 níveis) como fatores fixos e os sujeitos como fator aleatório. Para a comparação da ingestão alimentar, um modelo misto com tempo (2 níveis) e velocidade (2 níveis) como fatores fixos e sujeitos como fator aleatório foi utilizado. Para verificar a homogeneidade dos grupos, a comparação dos torques isométricos após a divisão dos grupos foi utilizado teste $t$ 
para amostras independentes. O mesmo procedimento foi adotado para análise do torque e impulso totais produzidos ao longo da sessão experimental. Para a comparação do trabalho e impulso produzidos série a série ao longo da sessão experimental, um modelo misto com fatores fixos, série (5 níveis) e velocidade (2 níveis) e fatores aleatórios, sujeitos, foi utilizado. Em caso de valores de $\mathrm{F}$ significantes, foi conduzido teste post-hoc com ajuste de Tukey para efeito de comparação múltipla. O nível de significância adotado foi de p<0,05.

\section{RESULTADOS}

\subsection{Torque isométrico máximo}

Os valores de torque isométrico máximo foram utilizados para o ranqueamento dos sujeitos e divisão aleatória dos grupos. Após o procedimento de aleatorização, a análise estatística não apresentou diferenças significantes entre os grupos. A Figura 5 ilustra os valores de torque isométrico para os grupos Exc20 e Exc210.

\subsection{Pico de torque durante a sessão experimental}

O pico de torque de cada série de exercício excêntrico e o maior valor obtido ao longo das séries, para os dois grupos, foi identificado. Não foram encontradas diferenças significantes intra e inter grupos. As Figuras 6 e 7 ilustram 
os valores de pico de torque ao longo das séries de exercício excêntrico e o maior valor entre as séries.

\subsection{Trabalho produzido durante a sessão experimental}

Foi também calculado, o trabalho produzido pelos sujeitos durante a sessão experimental. Ao analisarmos tanto o trabalho total (Figura 8) quanto o trabalho em cada uma das cinco séries de exercício (Figura 9), não encontramos diferenças significantes entre os grupos.

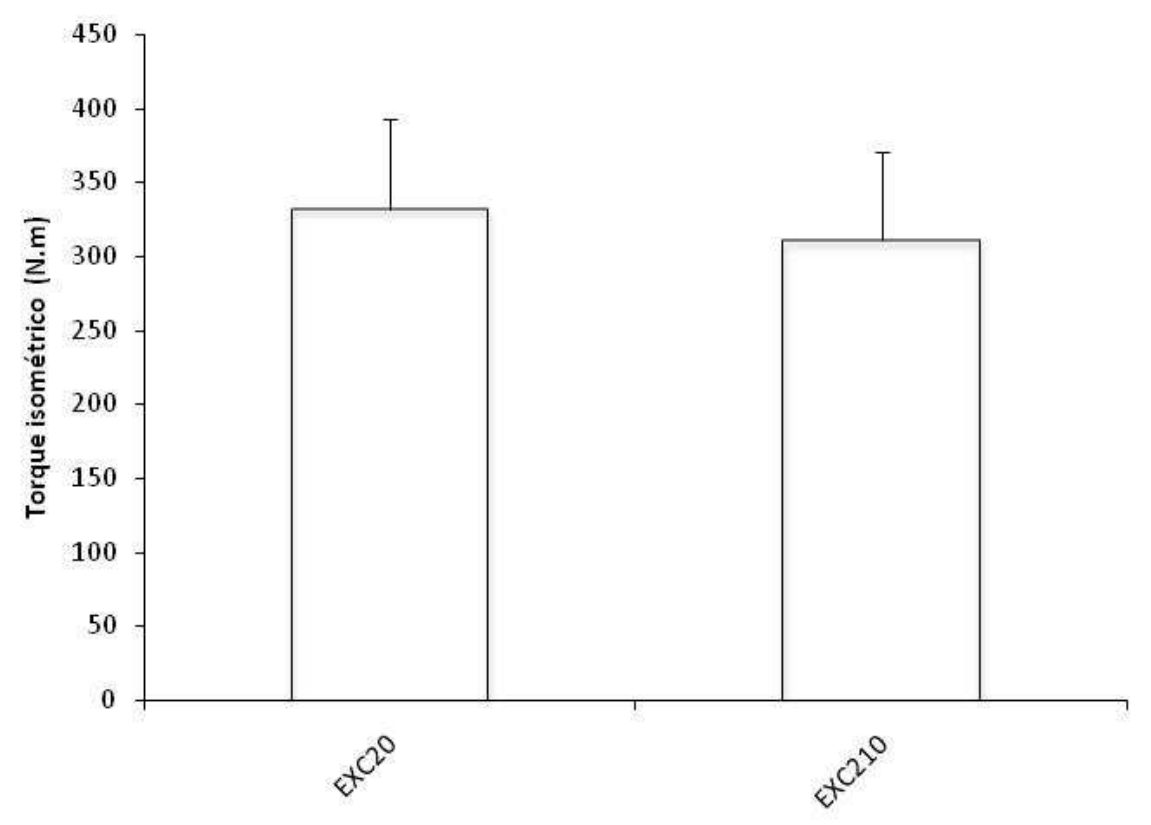

FIGURA 5 - Torque isométrico máximo para os grupos Exc20 $(20 \%$ s) $(n=11)$ e $\operatorname{Exc} 210\left(210^{\circ} / \mathrm{s}\right)(\mathrm{n}=9)$. 


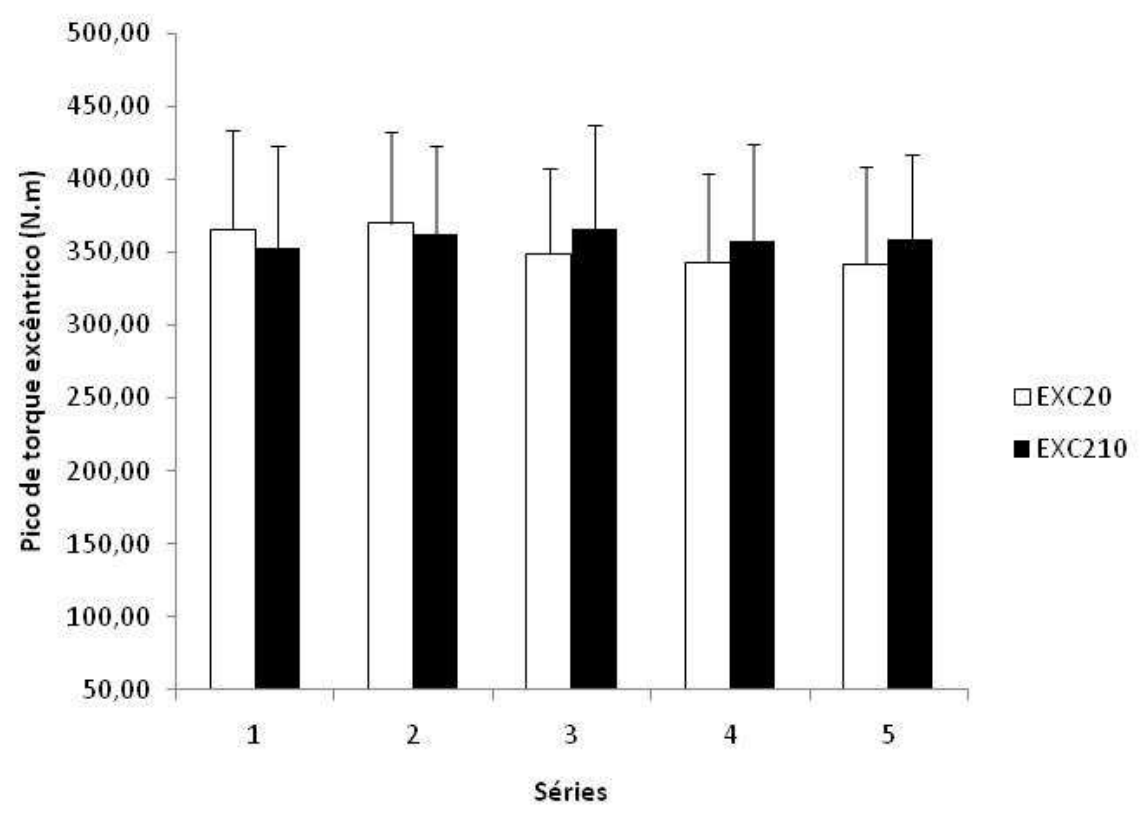

FIGURA 6 - Pico de torque em cada série de exercício excêntrico para os grupos $\operatorname{Exc} 20(20 \%)(n=11)$ e $\operatorname{Exc} 210(210 \%)(n=9)$.

\subsection{Impulso produzido durante a sessão experimental}

O cálculo do impulso foi realizado em função do torque e do tempo de produção de torque. Os valores de impulso total e por série foram significantemente maiores para o grupo EXC20 em comparação ao grupo EXC210. As Figuras 10 e 11 ilustram os valores totais e por série do impulso, respectivamente. 


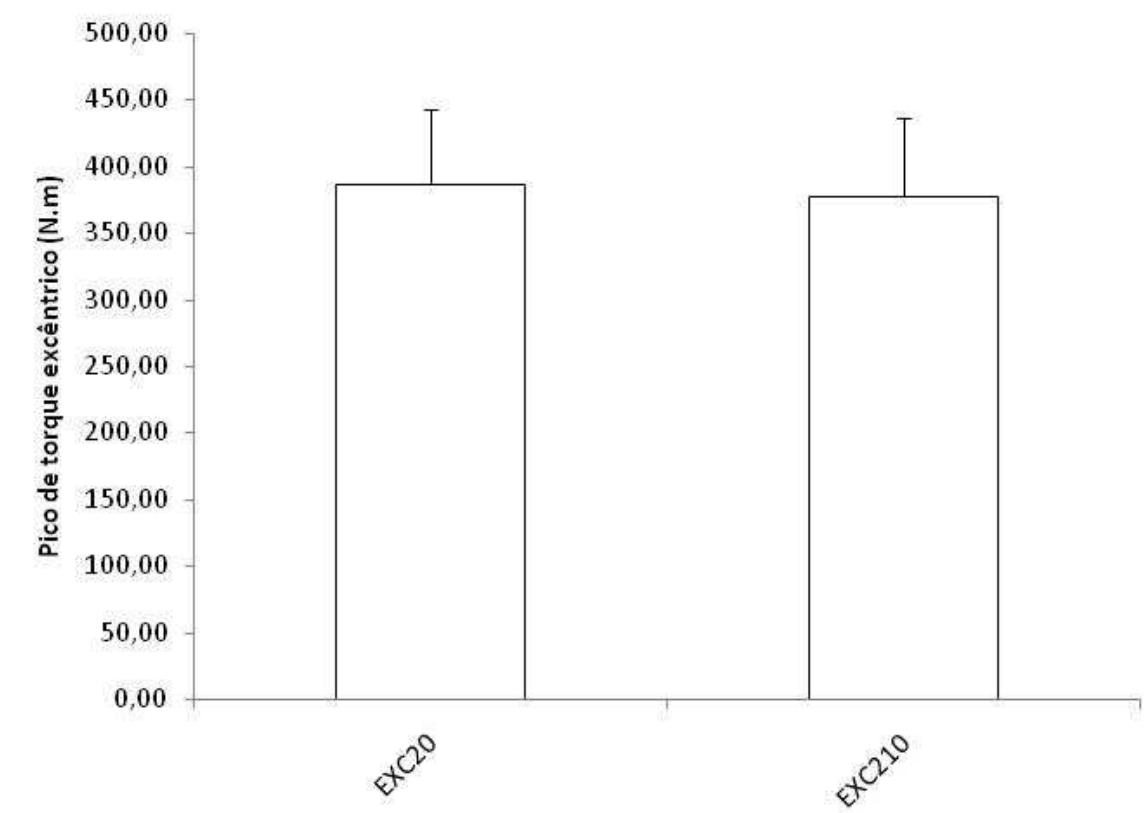

FIGURA 7 - Maior valor de pico de torque excêntrico para os grupos Exc20 $\left(20^{\circ} / \mathrm{s}\right)(\mathrm{n}=11)$ e $\operatorname{Exc} 210\left(210^{\circ} / \mathrm{s}\right)(\mathrm{n}=9)$.

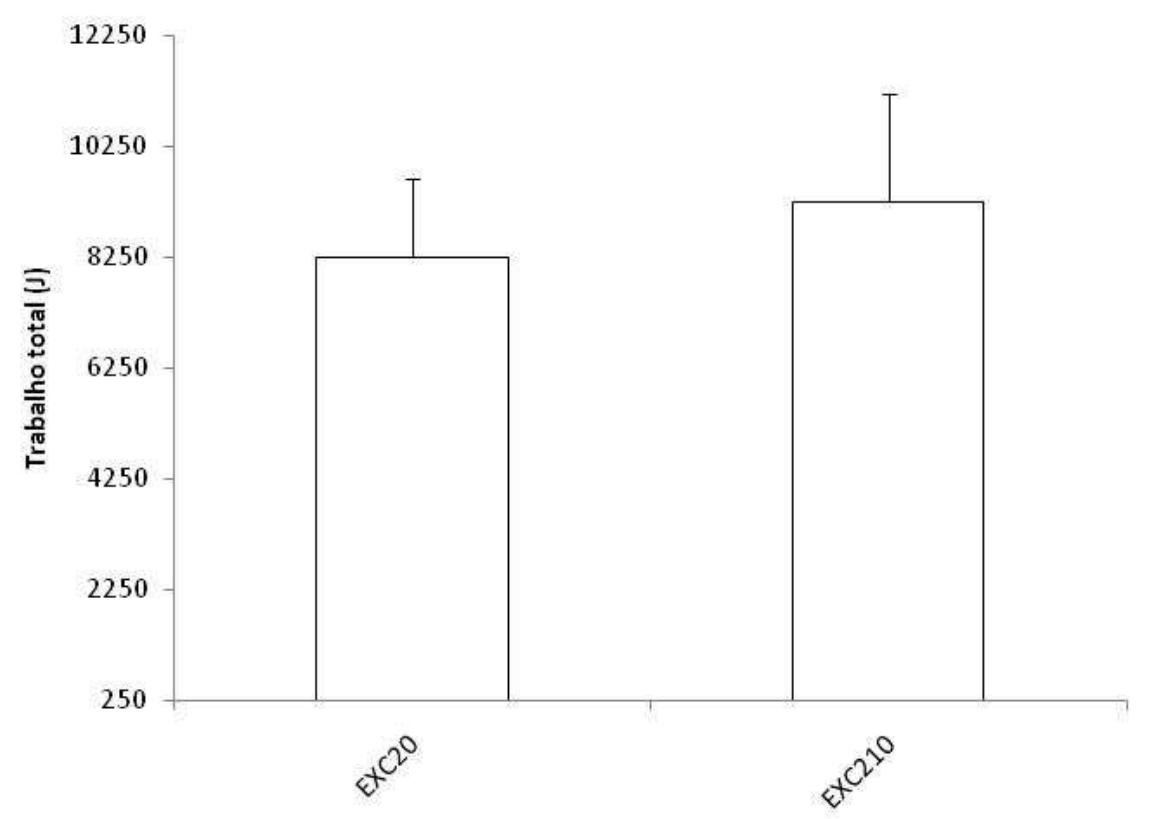

FIGURA 8 - Trabalho total produzido pelos grupos Exc20 (20\%s) n=(11) e Exc210 $(210 \%)(n=9)$ durante a sessão experimental. 


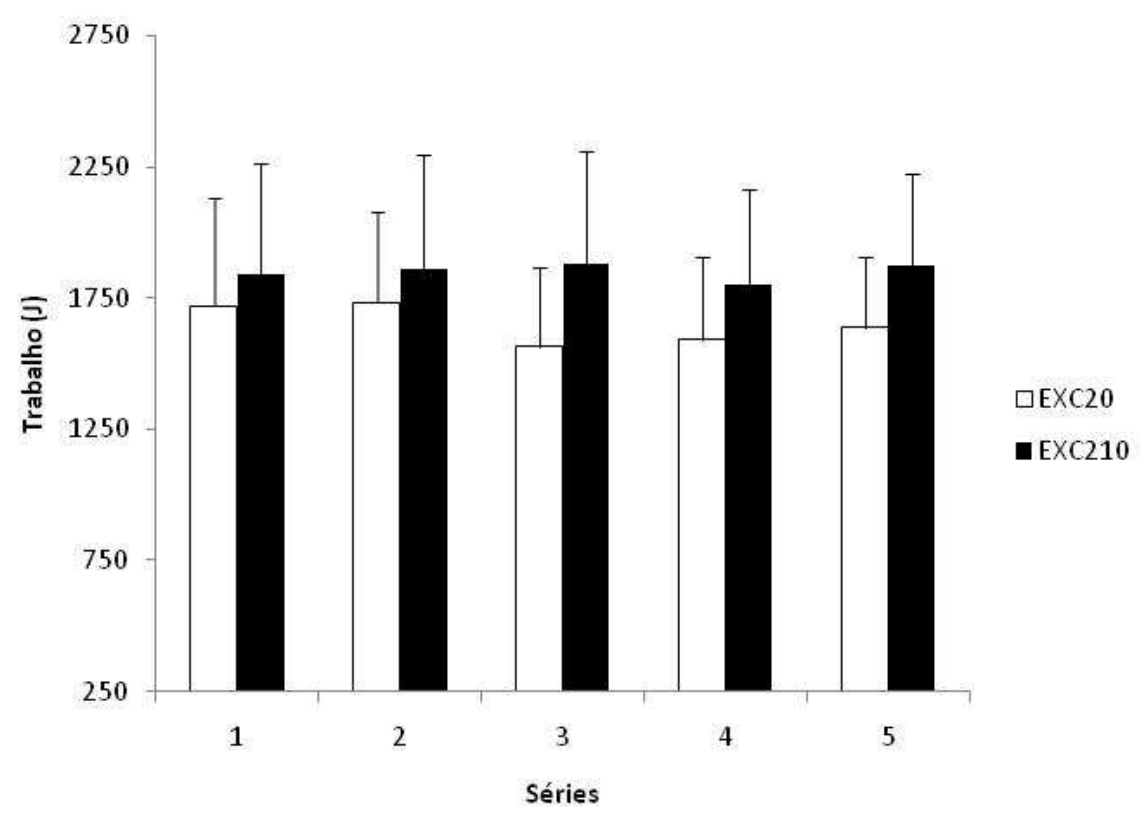

FIGURA 9 - Trabalho produzido pelos grupos Exc20 (20\%) $(n=11)$ e Exc210 $(210 \%)(n=9)$ por série de exercício durante a sessão experimental.

\subsection{Quantificação das proteínas Akt total e Akt fosforilada (pAkt)}

A análise dos dados de Akt total não mostrou diferenças significantes entre os grupos em nenhum dos tempos analisados. Já a análise da pAkt indicou efeito principal de tempo. Tanto o grupo EXC20, quanto o grupo EXC210 apresentaram valores maiores de pAkt nos tempos imediatamente e $2 \mathrm{~h}$ após o procedimento experimental em relação aos valores basais. Contudo, não houve diferenças entre os grupos. As Figuras 12 e 13 apresentam os dados de Akt e pAkt, respectivamente. 


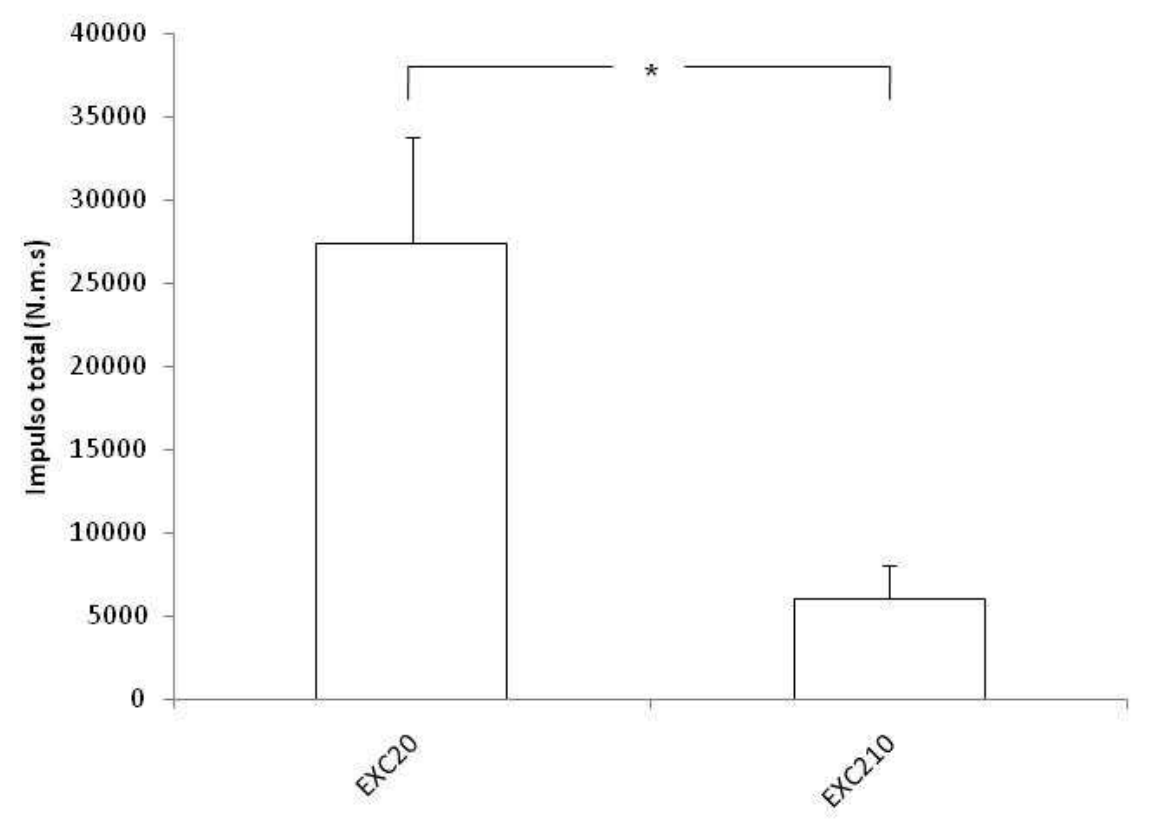

FIGURA 10 - Impulso total produzido durante a sessão experimental. * Indica diferença entre grupos $(\mathrm{p}<0,05)$. EXC20 $(n=11)$; EXC210 $(n=9)$.

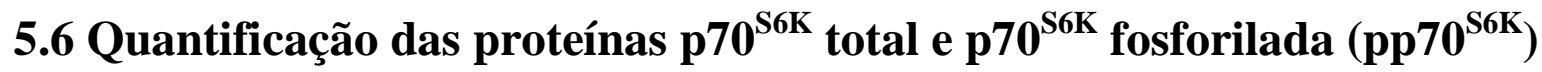

De maneira similar, a análise da proteína $\mathrm{p} 70^{\mathrm{S} 6 \mathrm{~K}}$ total não retornou diferenças significantes entre os grupos. Já a análise da mesma proteína na sua forma fosforilada indicou um efeito principal de tempo, onde se observou um aumento na pp70 $70^{\mathrm{S} 6 \mathrm{~K}}$ tanto imediatamente quanto $2 \mathrm{~h}$ após o término do exercício excêntrico em relação ao controle. Novamente, não foram observadas diferenças significantes entre os grupos. As Figuras 14 e 15 ilustram as respostas de $\mathrm{p} 70^{\mathrm{S} 6 \mathrm{~K}} \mathrm{e}$ $\mathrm{pp} 70^{\mathrm{S} 6 \mathrm{~K}}$ respectivamente. 


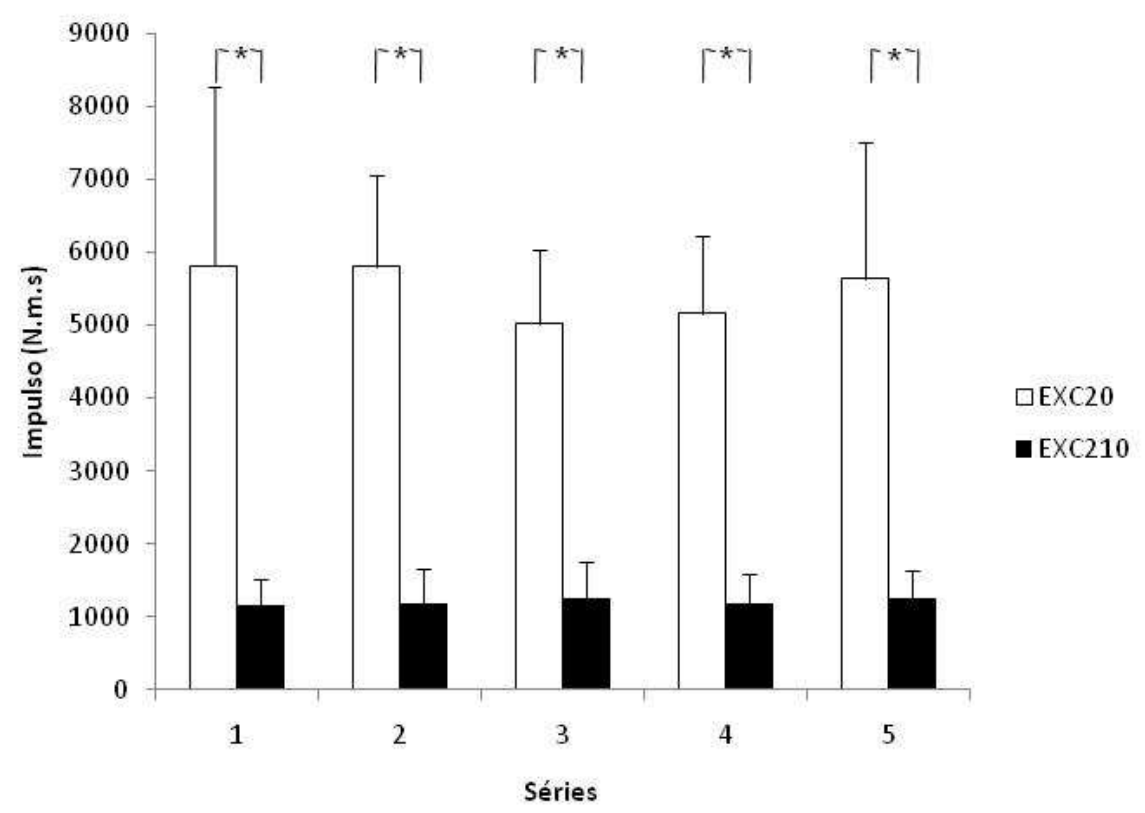

FIGURA 11 - Impulso produzido por série de exercício durante a sessão experimental. * Indica diferença entre os grupos para a mesma série $(\mathrm{p}<0,05)$. $\operatorname{EXC} 20(n=11) ; \operatorname{EXC} 210(n=9)$.

\subsection{Expressão gênica de MGF}

Observou-se um aumento significante para RNAm de MGF no grupo EXC20 no tempo 2 horas em comparação ao tempo controle. Contudo, não foram encontradas diferenças na expressão de MGF intra grupos nos diferentes tempos. A Figura 16 apresenta os dados de MGF para ambos os grupos. 


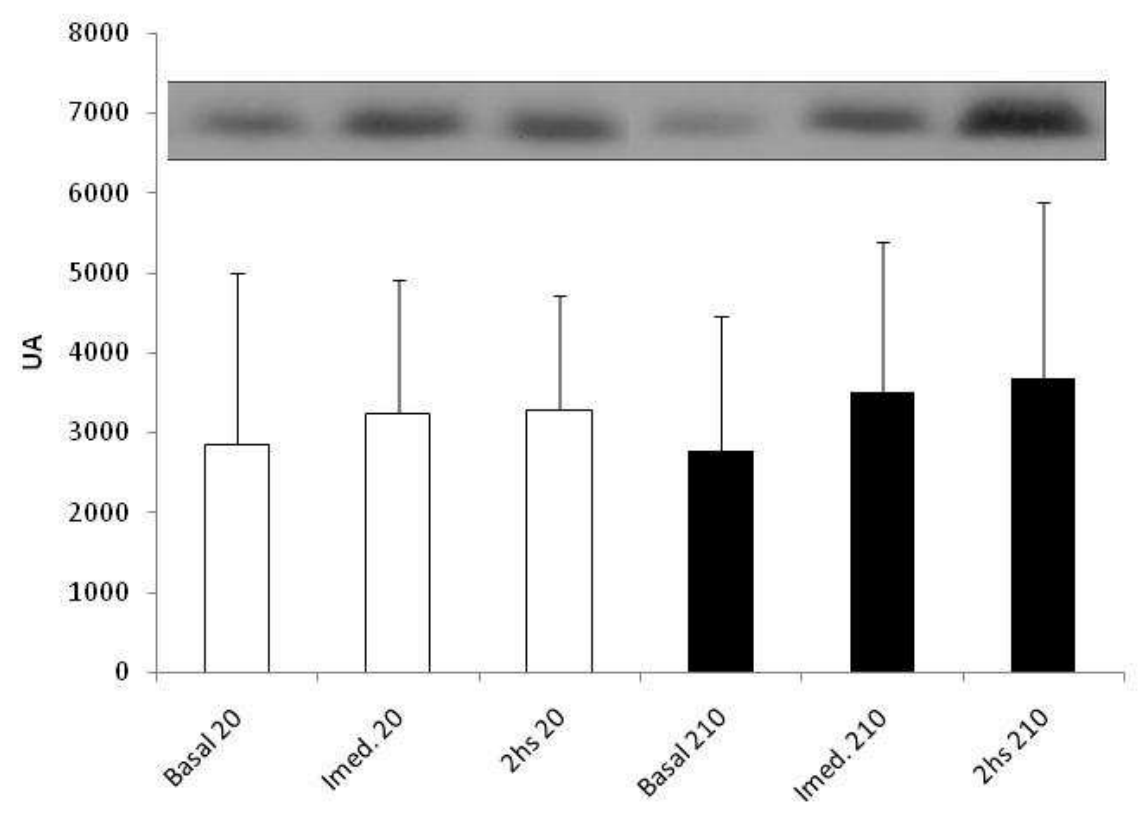

FIGURA 12 - Quantificação da proteína Akt total para os grupos EXC20 (n=11) e EXC210 (n=9). Basal20 = Pré intervenção para o grupo EXC20; Imed.20 = Imediatamente após o exercício excêntrico para o grupo EXC20; 2 hs20 = 2 horas após o exercício excêntrico para o grupo EXC20. Basal210 = Pré intervenção para o grupo EXC210; Imed.210 = Imediatamente após o exercício excêntrico para o grupo EXC210; 2hs 210 = 2 horas após o exercício excêntrico para o grupo EXC210. 


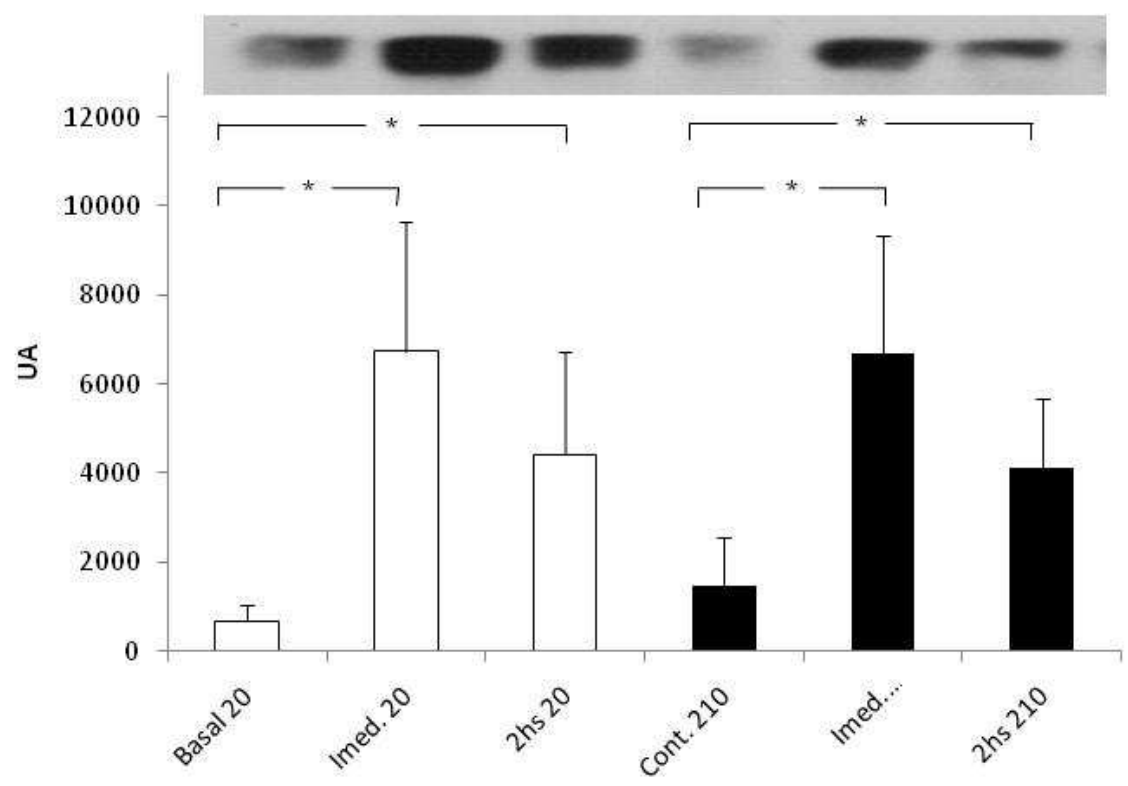

FIGURA 13 - Quantificação da proteína pAkt (Akt fosforilada) para os grupos EXC20 (n=11) e EXC210 (n=9). Basal20 = Pré intervenção para o grupo EXC20; Imed.20 = Imediatamente após o exercício excêntrico para o grupo EXC20; $2 \mathrm{hs} 20=2$ horas após o exercício excêntrico para o grupo EXC20. Basal210 = Pré intervenção para o grupo EXC210; Imed.210 = Imediatamente após o exercício excêntrico para o grupo EXC210; 2 hs210 $=2$ horas após o exercício excêntrico para o grupo EXC210. * Indica diferença em relação ao controle $(\mathrm{p}<0,05)$. 


\subsection{Expressão gênica de mTOR}

Não foram observadas diferenças significantes na análise da expressão gênica de mTOR intra ou inter grupos em nenhum dos tempos analisados. A Figura 17 apresenta os dados de mTOR RNAm.

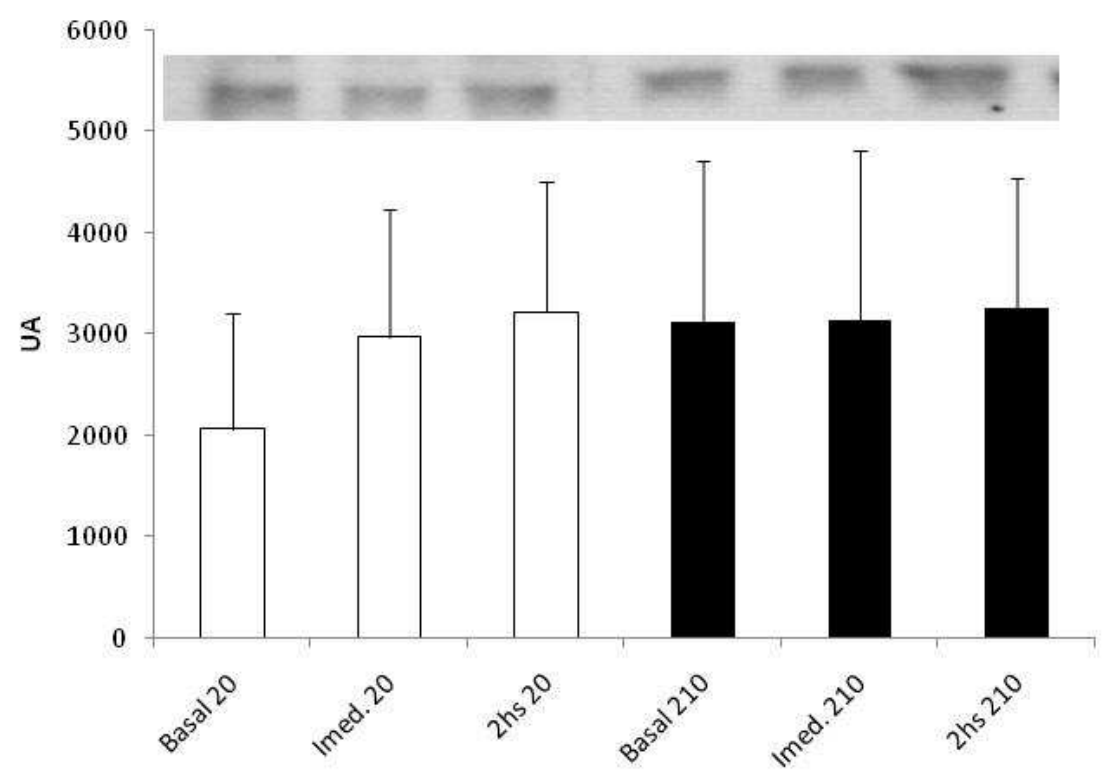

FIGURA 14 - Quantificação da proteína p70 ${ }^{\mathrm{S} 6 \mathrm{~K}}$ total para os grupos EXC20 $(n=11)$ e EXC210 (n=9). Basal20 = Pré intervenção para o grupo EXC20; Imed.20 = Imediatamente após o exercício excêntrico para o grupo EXC20; $2 \mathrm{hs} 20=2$ horas após o exercício excêntrico para o grupo EXC20. Basal210 = Pré intervenção para o grupo EXC210; Imed.210 = Imediatamente após o exercício excêntrico para o grupo EXC210; 2hs210 = 2 horas após o exercício excêntrico para o grupo EXC210. 


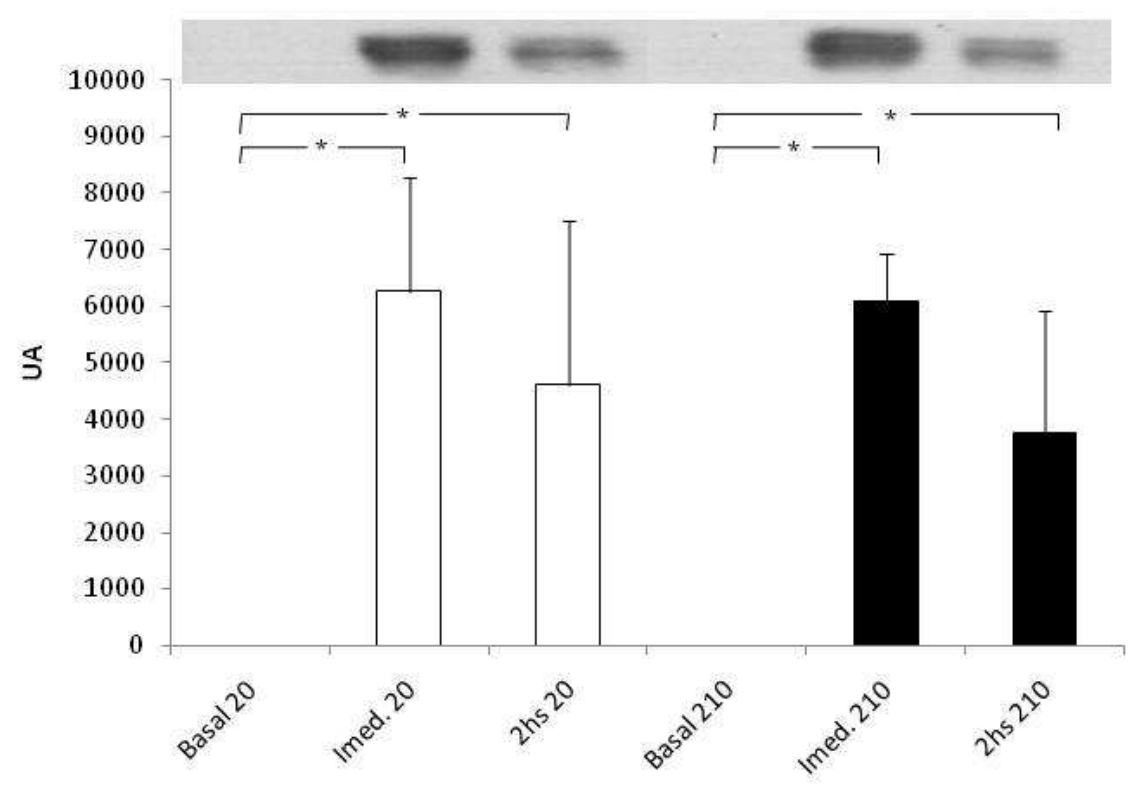

FIGURA 15 - Quantificação da proteína $\mathrm{p} 70^{\mathrm{S} 6 \mathrm{~K}}$ fosforilada $\left(\mathrm{pp} 70^{\mathrm{S} 6 \mathrm{~K}}\right)$ para os grupos EXC20 $(n=10)$ e EXC210 $(n=9)$. Basal20 = Pré intervenção para o grupo EXC20; Imed.20 = Imediatamente após o exercício excêntrico para o grupo EXC20; 2 hs $20=2$ horas após o exercício excêntrico para o grupo EXC20. Basal210 = Pré intervenção para o grupo EXC210; Imed.210 = Imediatamente após o exercício excêntrico para o grupo EXC210; $2 \mathrm{hs} 210=2$ horas após o exercício excêntrico para o grupo EXC210. * Indica diferença em relação ao controle $(\mathrm{p}<0,05)$. 


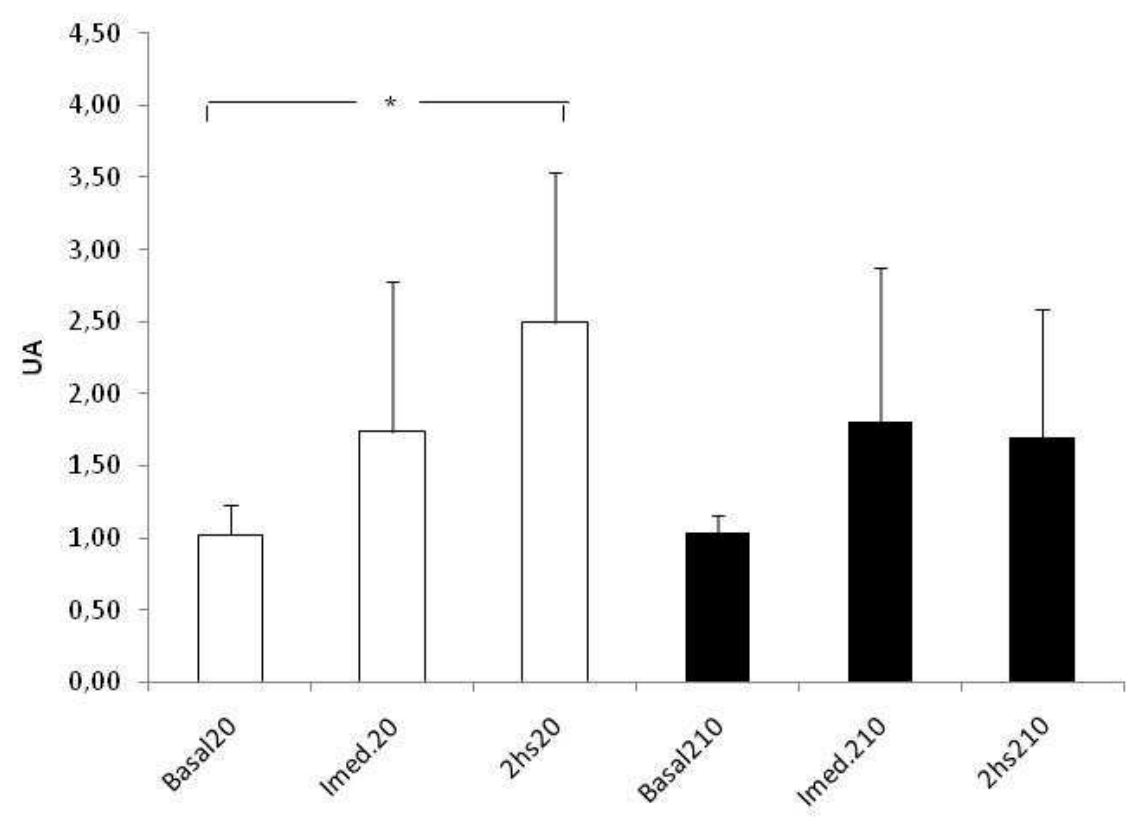

FIGURA 16 - Expressão gênica de MGF para os grupos EXC20 (n=10) e EXC210 $(n=8)$. Basal20 = Pré intervenção para o grupo EXC20; Imed.20 = Imediatamente após o exercício excêntrico para o grupo EXC20; $2 \mathrm{hs} 20$ = 2 horas após o exercício excêntrico para o grupo EXC20. Basal210 = Pré intervenção para o grupo EXC210; Imed.210 = Imediatamente após o exercício excêntrico para o grupo EXC210; 2hs 210 = 2 horas após o exercício excêntrico para o grupo EXC210. * Indica diferença em relação ao controle $(p<0,05)$. 


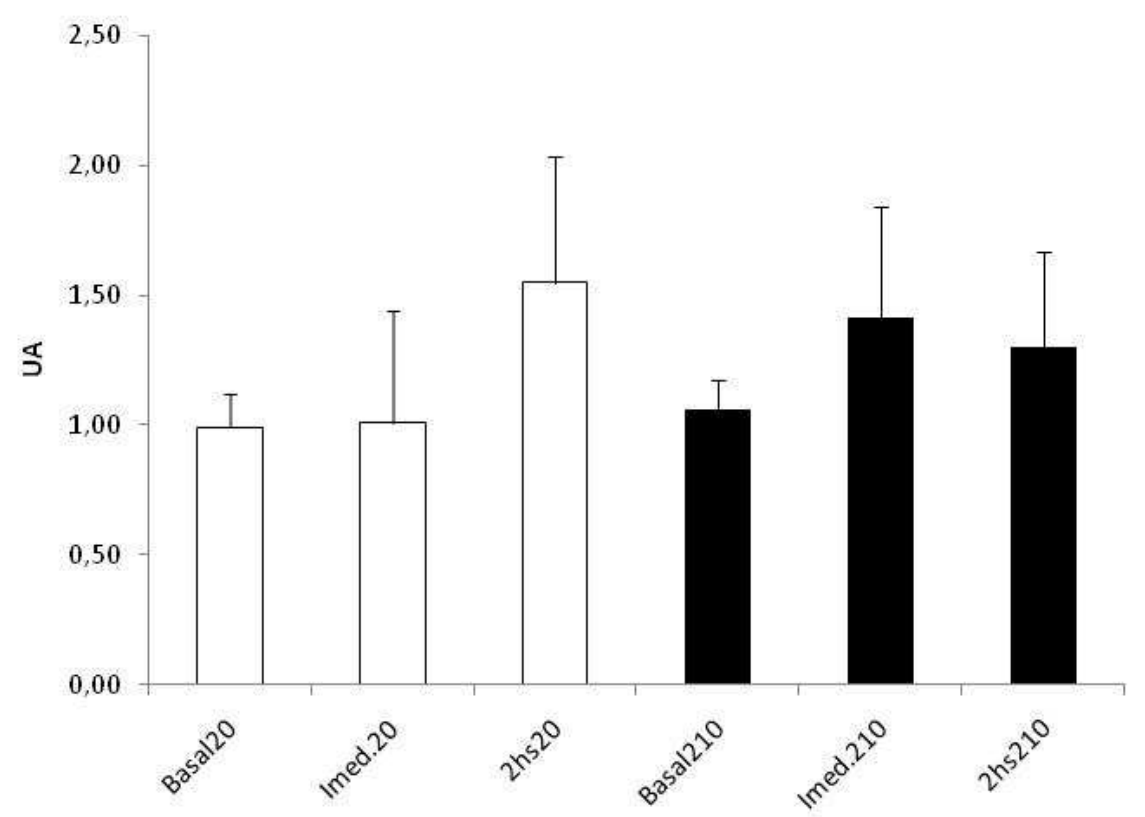

FIGURA 17 - Expressão gênica de mTOR para os grupos EXC20 (n=11) e EXC210 (n=9). Basal20 = Pré intervenção para o grupo EXC20; Imed.20 = Imediatamente após o exercício excêntrico para o grupo EXC20; 2 hs $20=2$ horas após o exercício excêntrico para o grupo EXC20. Basal210 = Pré intervenção para o grupo EXC210; Imed.210 = Imediatamente após o exercício excêntrico para o grupo EXC210; $2 \mathrm{hs} 210$ = 2 horas após o exercício excêntrico para o grupo EXC210.

\section{DISCUSSÃO}

O objetivo do trabalho foi verificar o efeito de uma sessão aguda de exercício excêntrico desempenhado em velocidade baixa $\left(20^{\circ} / \mathrm{s}\right)$ ou alta $\left(210^{\circ} / \mathrm{s}\right)$ sobre a fosforilação das proteínas Akt e $\mathrm{p} 70^{\mathrm{S} 6 \mathrm{~K}}$ participantes da via de sinalização 
intracelular da hipertrofia muscular PI3K/Akt/mTOR/p70 ${ }^{\mathrm{S} 6 \mathrm{~K}}$. Adicionalmente, foi objetivo do estudo, verificar o efeito da mesma manipulação do exercício sobre a expressão gênica do fator de crescimento MGF e da proteína mTOR.

Nossa hipótese assumia que as AE desempenhadas em alta velocidade consistiriam em um estímulo mais potente para a fosforilação e a expressão das proteínas em questão, constituindo um estímulo de melhor qualidade para a promoção da hipertrofia muscular. O principal achado do estudo foi a não observância de diferenças significantes entre as velocidades das AE, tanto para a fosforilação quanto para a expressão gênica das variáveis escolhidas.

Ao analisarmos os resultados de ingestão nutricional, podemos assumir que embora o fator nutricional desempenhe um papel importante na resposta das vias (BOLSTER, JEFFERSON \& KIMBALL, 2004; BOLSTER, VARY, KIMBALL \& JEFFERSON, 2004; CUTHBERTSON, SMITH, BABRAJ, LEESE, WADDELL, ATHERTON, WACKERHAGE, TAYLOR \& RENNIE, 2005; FUJITA, DREYER, DRUMMOND, GLYNN, CADENAS, YOSHIZAWA, VOLPI \& RASMUSSEN, 2007), esta não foi uma variável interveniente nos resultados.

Considerando os dados obtidos no dinamômetro isocinético, podemos observar que após o ranqueamento e aleatorização dos sujeitos, a divisão dos grupos se mostrou bastante homogênea, uma vez que a média dos torques 
isométricos máximos dos grupos não foi diferente (Figura 5). Adicionalmente, o pico de torque não variou de forma significante entre os grupos, confirmando a proposição de que não há diminuição da produção de força com o aumento da velocidade das AE (EDMAN, 1992). O mesmo pode ser dito ao analisarmos o maior valor de pico de torque excêntrico obtido em todas as repetições. Outra forma interessante de se verificar a diferença na magnitude do estímulo é através da avaliação do trabalho produzido durante o exercício. Os dados de trabalho total ao longo do exercício e os dados de trabalho produzido em cada série, não revelaram diferenças significantes, mostrando mais uma vez que a magnitude do estímulo foi similar, o que nos permitiria em última instância, atribuir quaisquer diferenças nas variáveis dependentes selecionadas à velocidade da ação muscular.

Contudo, é importante citar que apesar da magnitude do estímulo ter-se mostrado similar entre os grupos, CHAPMAN et al. (2008) sugerem que a velocidade alta de AE pode incorrer em maior stress mecânico no tecido muscular, uma vez que nesta condição, teríamos menor interação entre miofilamentos, passando a depender de maior força passiva para o output total de força. Segundo nossa proposição inicial, este maior stress mecânico poderia, em tese, ser responsável pela maior ativação da via em questão.

Um dado esperado é a diferença significante dos valores tanto de impulso total, quanto do produzido por série de exercício entre os grupos. O cálculo do 
impulso é dependente do torque e do tempo de produção de força (CREWTHER, CRONIN \& KEOGH, 2005). O tempo para produção de força é determinado pela velocidade da $\mathrm{AE}$, e estas eram bastante distintas entre si. O grupo EXC20 realizou $\mathrm{AE}$ na velocidade de $20 \%$, o que na amplitude de movimento designada no estudo $\left(90^{\circ}\right)$ correspondeu a 4,5 segundos de produção de força. Já no grupo EXC210, que realizou o exercício à $210^{\circ}$ s, o tempo para produção de força foi aproximadamente 10 vezes menor (0,43 segundos). Dado que o torque produzido entre os grupos foi similar, a disparidade no tempo de produção explica a diferença observada nos valores de impulso.

CREWTHER, CRONIN e KEOGH (2005) destacam a importância de se considerar o impulso e não somente o tempo sob tensão. Os autores discutem a relevância da análise do tempo sob tensão isolado sobre o efeito hipertrófico, uma vez que a simples mensuração do volume (o que estaria relacionado com o tempo sob tensão) não explicaria diferenças na magnitude da resposta de hipertrofia em modelos distintos de treinamento, isto é, sem levar em consideração a força desenvolvida, e em conseqüência, o grau de tensão aplicado na musculatura.

Poucos trabalhos se dedicaram ao estudo do tempo sob tensão sobre a resposta hipertrófica. GILLIES, PUTMAN e BELL (2006) estudaram os tempos relativos sob tensão das ações concêntricas e excêntricas submáximas e a resposta hipertrófica em um grupo de mulheres com experiência prévia em treinamento de 
força. As participantes foram divididas em dois grupos, um realizou as ações concêntricas em seis segundos e as excêntricas em dois segundos, o outro fez o contrário, aumentando o tempo das $\mathrm{AE}$ e diminuindo das concêntricas. Os resultados revelaram que apesar da intervenção sobre os tempos de ação excêntrica e concêntrica, a carga utilizada nas sessões de treinamento e a progressão de carga ao longo do período experimental foram semelhantes entre os grupos. Adicionalmente, os autores não encontraram diferenças entre os grupos para o aumento área da secção transversa (AST) da musculatura treinada. Embora a relação destes dados com o modelo proposto neste estudo seja extremamente limitada, os resultados apontam para a não existência de um efeito significante da manipulação do tempo sob tensão quando ações musculares submáximas são utilizadas. Em nosso estudo, devido à natureza do exercício excêntrico, todas as repetições eram realizadas em caráter máximo. Infelizmente, não há menção na literatura sobre a relação entre o tempo sob tensão ou o impulso, e a ativação das vias de hipertrofia.

Ao analisarmos os dados de fosforilação das proteínas downstream da via $\mathrm{PI} 3 \mathrm{~K} / \mathrm{Akt} / \mathrm{mTOR} / \mathrm{p} 70^{\mathrm{S} 6 \mathrm{~K}}$, podemos observar que a manipulação da velocidade não exerceu um efeito diferenciador sobre a pAkt ou $\mathrm{pp} 70^{\mathrm{S} 6 \mathrm{~K}}$. Ao contrário da nossa hipótese inicial, as $\mathrm{AE}$ velozes não foram capazes de fosforilar de forma significantemente maior as proteínas $\mathrm{Akt} e \mathrm{p} 70^{\mathrm{S} 6 \mathrm{~K}}$ em comparação às $\mathrm{AE}$ lentas. 
Em contrapartida, a fosforilação da Akt e da $\mathrm{p} 70^{\mathrm{S} 6 \mathrm{~K}}$ foi significantemente maior em relação à situação controle imediatamente $(973,85 \%$ e 425,49\%, respectivamente) e duas horas após exercício $(638,21 \%$ e $280,03 \%$, respectivamente). Embora não tenham sido observadas diferenças entre os grupos, estes dados mostram a eficiência do protocolo proposto em ativar a via de sinalização intracelular para a hipertrofia muscular.

A investigação do efeito do treinamento de força sobre as vias de hipertrofia é relativamente recente. A literatura ainda é escassa em estudos com modelos mais específicos de treinamento (análise isolada de AE, por exemplo) e suas relações com a fosforilação/expressão de proteínas ligadas ao crescimento muscular, principalmente usando modelos com seres humanos.

TERZIS et al. (2008) investigaram o efeito de uma sessão aguda de exercícios de força convencionais (contemplando ações concêntricas + excêntricas) sobre a fosforilação de proteínas chave na sinalização intracelular para hipertrofia muscular. Os autores verificaram aumentos significantes nas quantidades de mTOR e p70 ${ }^{\mathrm{S} 6 \mathrm{~K}}$ fosforiladas 30 minutos após a sessão de exercícios (aproximadamente 136,84\% e 500\%, respectivamente). Curiosamente, foi também observado uma redução na fosforilação da Akt pós-atividade (aproximadamente 47,83\%), o que mais uma vez sugere a redundância na 
sinalização, não estabelecendo necessariamente uma sequência de ativações em cascata entre estas proteínas.

Corroborando com os dados de TERZIS et al. (2008), KOOPMAN et al. (2006) encontraram aumento significante (aproximadamente 250\%) da fosforilação de $\mathrm{p} 70^{\mathrm{S} 6 \mathrm{~K}} 30$ minutos após 16 séries de 10 repetições de exercícios para membros inferiores (oito séries de leg-press e oito séries de extensão de joelhos) a 75\% 1RM.

Alguns estudos com modelo animal tentaram verificar a influência do estímulo mecânico sobre a ativação da via PI3K/Akt/mTOR/p70 ${ }^{\mathrm{S} 6 \mathrm{~K}}$. BOLSTER et al. (2003) utilizaram um modelo agudo de exercícios voluntários (através de condicionamento) por quatro dias observando um aumento de aproximadamente 280\% na fosforilação da Akt 10 minutos após o término do exercício. O mesmo foi observado para a proteína ribossomal S6 (aproximadamente 500\%), enquanto para $\mathrm{p} 70^{\mathrm{S} 6 \mathrm{~K}}$ foi verificado apenas uma tendência $(\mathrm{p}=0,06)$ a aumento. BURRY, HAWKINS e SPANGENBURG (2007) investigaram o papel de AE isoladas em comparação à ações isométricas na ativação da via em questão. Seis horas após a realização de exercícios involuntários (eletroestimulação) os autores encontraram fosforilação aumentada (aproximadamente $300 \%$ ) para a proteína $\mathrm{p} 70^{\mathrm{S} 6 \mathrm{~K}}$ apenas no grupo que realizou AE. 
De maneira mais similar ao nosso estudo, o trabalho de ELIASSON et al. (2006), estudou o efeito do tipo de ação muscular sobre a referida via, utilizando quatro séries de seis movimentos excêntricos máximos, porém com exercício isoinercial (leg press). A cadência do exercício foi fixada em 2,4 segundos por fase (excêntrica ou concêntrica), o que na amplitude de movimento utilizada pelos autores $\left(90^{\circ}\right)$, corresponde a aproximadamente a uma velocidade de $38 \%$ s. Embora os autores não tenham testado o efeito da velocidade, eles encontraram aumentos significantes na fosforilação da $\mathrm{p} 70^{\mathrm{S} 6 \mathrm{~K}}$ e da proteína ribossomal S6 no grupo que utilizou $\mathrm{AE}$ em comparação ao que realizou ações concêntricas. Contudo, utilizando o mesmo modelo acima, os autores não verificaram diferenças intra ou inter grupos na fosforilação da Akt, corroborando apenas em parte com os dados obtidos em nosso estudo, onde ambas as velocidades foram capazes de fosforilar a Akt.

Embora a comparação de nossos dados com a literatura seja bastante limitada (dado a disparidade dos modelos utilizados), guardadas as ressalvas inerentes às comparações, parece haver coerência dos nossos achados com os encontrados em outros trabalhos.Contudo, permanece não respondida a causa da superioridade do uso de $\mathrm{AE}$ velozes na indução de hipertrofia em caráter crônico. Os estudos de TERZIS et al. (2008) em humanos e o de BAAR e ESSER (1999) em animais estabelecem uma excelente correlação entre os eventos agudos de 
fosforilação das proteínas envolvidas na via da PI3K/Akt/mTOR/p70 ${ }^{\mathrm{S} 6 \mathrm{~K}} \mathrm{com}$ o aumento crônico de massa muscular. Porém, o mesmo parece não poder ser dito em relação a resposta aguda da via frente a manipulação da velocidade e o efeito crônico de aumento de massa muscular observado em outros estudos, como o de SHEPSTONE et al. (2005).

TERZIS et al. (2008) investigaram a relação entre a fosforilação de $\mathrm{p} 70^{\mathrm{S} 6 \mathrm{~K}}$ frente à um estímulo agudo de exercícios de força e o aumento de massa muscular após um período crônico de treinamento de força. A fase aguda envolveu seis séries de 6RM no aparelho leg-press com biópsias pré e após 30 min a realização da sessão. A fase crônica teve duração de 14 semanas, três vezes por semana e consistiu em um programa convencional de treinamento de força. Os autores observaram uma boa correlação do aumento da $\mathrm{p} 70^{\mathrm{S} 6 \mathrm{~K}}(\mathrm{r}=0.82)$ com o percentual de aumento na massa livre de gordura no período pós-treinamento $(2,3 \%$, p<0,05). Por outro lado, BAAR e ESSER (1999) optaram por um modelo experimental. Os autores submeteram os ratos a seis semanas de eletroestimulação de alta freqüência. Os resultados de aumento de massa muscular correlacionaram-se muito bem $(\mathrm{r}=0.998)$ com o aumento na fosforilação de p70 ${ }^{\mathrm{S} 6 \mathrm{~K}}$ após uma sessão aguda de eletroestimulação.

Os dados de expressão gênica de MGF poderiam ajudar a explicar o efeito da manipulação da velocidade, e teoricamente da tensão sobre o citoesqueleto 
muscular, na ativação da via. Contudo, não houve efeito do tratamento sobre a expressão de MGF. Embora os valores duas horas após o exercício sejam significantemente maiores para o grupo EXC20 em comparação ao basal, estes não são diferentes dos valores duas horas após no grupo EXC210, eliminando quaisquer inferências sobre o efeito da velocidade das AE.

Não se encontra na literatura atual, dados utilizando modelos similares para comparação com os valores obtidos em nosso trabalho. HEINEMEIER, OLESEN, HADDAD, LANGBERG, KJAER, BALDWIN e SCHJERLING (2007a) submeteram ratas a exercício agudo de força involuntário (eletroestimulação por quatro dias) envolvendo somente ações excêntricas, concêntricas ou isométricas. Os autores encontraram valores significantemente maiores na expressão de MGF para o grupo que realizou exercício excêntrico em comparação ao concêntrico, mas não ao isométrico.

Estudando seres humanos, HAMEED, ORRELL, COBBOLD, GOLDSPINK e HARRIDGE (2003) verificaram o efeito de 10 séries de seis repetições na cadeira extensora a 80\% 1RM. As biópsias foram obtidas duas horas e meia após o término do exercício. Embora os resultados tenham sido significantemente maiores para a avaliação pós, eles revelaram uma grande variabilidade na resposta (aumentos em relação ao controle variaram de $2 \%$ à 864\%), indicando a importância da individualidade biológica nesta resposta. 
Em um estudo recente, LIU, HEINICHEN, WIRTH, SCHMIDTBLEICHER e STEINACKER (2008) submeteram 24 indivíduos a seis semanas de treinamento de força utilizando contrações máximas ou treinamento de força com contrações máximas, movimentos balísticos e com exercícios que envolviam o ciclo alongamento-encurtamento. Os autores obtiveram amostras musculares três dias antes do início e sete dias após o término do período de treinamento. Ambos os grupos mostraram aumentos significantes de MGF em relação à condição basal, contudo o grupo que utilizou ações musculares máximas apresentou um upregulation mais acentuado (1160\%) em relação ao grupo com treinamento misto (59\%). Apesar da diferença na resposta, os grupos não foram diferentes entre si. Os autores discutem a importância do aumento de MGF na estimulação de células satélite e conseqüente indução da hipertrofia muscular.

Com relação à expressão de mTOR, também não foram observadas mudanças significantes intra ou inter grupos para esta variável. Assim como para o MGF, não só o tempo das coletas de tecido muscular como o exercício em caráter agudo podem ter sido determinantes para a não observância de diferenças nestas variáveis. A literatura é ainda mais escassa em informações sobre a resposta da expressão de mTOR frente a estímulos similares ao empregado em nosso estudo. Em um estudo recente, utilizando sujeitos jovens (idade média de 29 anos e $n=6$ ) e idosos (idade média de 70 anos e n=6), DRUMMOND, 
MIYAZAKI, DREYER, PENNINGS, DHANANI, VOLPI, ESSER e RASMUSSEN (2008) verificaram o efeito de exercício de força agudo (oito séries de 10 movimentos de extensão de joelhos a 70\% 1RM) na expressão gênica de proteínas ligadas à sinalização pela mTOR. Amostras de tecido muscular foram obtidas antes do exercício e uma hora após o término do exercício. Adicionalmente, os autores realizaram mais duas coletas, a três e seis horas após o término do exercício. Contudo, é importante ressaltar que a coleta tecidual de uma hora após o exercício foi seguida pela ingestão de uma solução contendo uma mistura de aminoácidos essenciais enriquecida em leucina (20g), limitando, portanto a comparação dos resultados referentes aos tempos três e seis horas pós exercício com o nosso estudo. Mesmo considerando a intervenção feitas pelos autores, não foram identificadas diferenças para nenhum dos grupos ao longo dos tempos, nem mesmo diferença inter grupos para a expressão gênica de mTOR. Contudo, os autores mostraram diminuição na expressão de REDD2 (um regulador negativo da sinalização de mTOR) para ambos os grupos, e aumento na expressão de Rheb (um regulador positivo da sinalização de mTOR) nos indivíduos jovens após o exercício físico agudo mais a suplementação.

Adicionalmente, é importante lembrar que não se conhece a resposta de ativação das vias e expressão de MGF e mTOR frente à manipulação do tempo sob tensão. Desta forma, como perspectivas futuras de estudo, a equalização do 
impulso entre os grupos pode constituir uma estratégia interessante para se tentar demonstrar o efeito da manipulação da velocidade sobre as variáveis em questão. Além disso, uma vez que o aumento crônico de massa muscular está intimamente ligado ao equilíbrio entre síntese e degradação protéicas (TOIGO \& BOUTELLIER, 2006), é possível que a manipulação da velocidade atue de forma diferenciada não sobre o estímulo anabólico, mas sim sobre as vias de degradação. Portanto, a investigação da fosforilação e expressão de proteínas ligadas ao mecanismo de degradação muscular ajudariam a elucidar esta questão.

Em conclusão, observamos que as diferentes velocidades de exercício excêntrico desempenhadas em caráter agudo, se mostraram igualmente eficientes em desencadear a fosforilação de proteínas chave da via sinalização da hipertrofia $\left(\mathrm{PI} 3 \mathrm{~K} / \mathrm{Akt} / \mathrm{mTOR} / \mathrm{p} 70^{\mathrm{S} 6 \mathrm{~K}}\right)$, não atuando, contudo, sobre a expressão gênica de MGF e mTOR. 


\section{REFERÊNCIAS BIBLIOGRÁFICAS}

AAGAARD, P.; SIMONSEN, E.B.; ANDERSEN, J.L.; MAGNUSSON, S.P.; HALKJAER-KRISTENSEN, J.; DYHRE-POULSEN, P. Neural inhibition during maximal eccentric and concentric quadriceps contraction: effects of resistance training. Journal of Applied Physiology, v.89, n.6, p.2249-57, 2000.

AMIRIDIS, I.G.; MARTIN, A.; MORLON, B.; MARTIN, L.; COMETTI, G.; POUSSON, M.; VAN HOECKE, J. Co-activation and tension-regulating phenomena during isokinetic knee extension in sedentary and highly skilled humans. European Journal of Applied Physiology and Occupational Physiology, v.73, n.1-2, p.149-56, 1996.

AOKI, M.S.; MIYABARA, E.H.; SOARES, A.G.; SAITO, E.T.; MORISCOT, A.S. mTOR pathway inhibition attenuates skeletal muscle growth induced by stretching. Cell Tissue Research, v.324, n.1, p.149-56, 2006.

BAAR, K.; ESSER, K. Phosphorylation of p70(S6k) correlates with increased skeletal muscle mass following resistance exercise. American Journal of Physiology, v.276, n.1 Pt 1, p.C120-7, 1999. 
BODINE, S.C.; STITT, T.N.; GONZALEZ, M.; KLINE, W.O.; STOVER, G.L.; BAUERLEIN, R.; ZLOTCHENKO, E.; SCRIMGEOUR, A.; LAWRENCE, J.C.; GLASS, D.J.; YANCOPOULOS, G.D. Akt/mTOR pathway is a crucial regulator of skeletal muscle hypertrophy and can prevent muscle atrophy in vivo. Nature Cell Biology, v.3, n.11, p.1014-9, 2001.

BOLSTER, D.R.; JEFFERSON, L.S.; KIMBALL, S.R. Regulation of protein synthesis associated with skeletal muscle hypertrophy by insulin-, amino acidand exercise-induced signalling. Proceedings of the Nutrition Society, v.63, n.2, p.351-6, 2004.

BOLSTER, D.R.; KUBICA, N.; CROZIER, S.J.; WILLIAMSON, D.L.; FARRELL, P.A.; KIMBALL, S.R.; JEFFERSON, L.S. Immediate response of mammalian target of rapamycin (mTOR)-mediated signalling following acute resistance exercise in rat skeletal muscle. Journal of Physiology, v.553, n.Pt 1, p.213-20, 2003.

BOLSTER, D.R.; VARY, T.C.; KIMBALL, S.R.; JEFFERSON, L.S. Leucine regulates translation initiation in rat skeletal muscle via enhanced eIF4G phosphorylation. Journal of Nutrition, v.134, n.7, p.1704-10, 2004. 
BOPPART, M.D.; BURKIN, D.J.; KAUFMAN, S.J. Alpha7beta1-integrin regulates mechanotransduction and prevents skeletal muscle injury. American Journal of Physiology - Cell Physiology, v.290, n.6, p.C1660-5, 2006.

BURKHOLDER, T.J. Mechanotransduction in skeletal muscle. Frontiers in Bioscience, v.12, p.174-91, 2007.

BURRY, M.; HAWKINS, D.; SPANGENBURG, E.E. Lengthening contractions differentially affect $\mathrm{p} 70 \mathrm{~s} 6 \mathrm{k}$ phosphorylation compared to isometric contractions in rat skeletal muscle. European Journal of Applied Physiology, v.100, n.4, p.409-15, 2007.

CANTLEY, L.C. The phosphoinositide 3-kinase pathway. Science, v.296, n.5573, p.1655-7, 2002.

CARSON, J.A.; WEI, L. Integrin signaling's potential for mediating gene expression in hypertrophying skeletal muscle. Journal of Applied Physiology, v.88, n.1, p.337-43, 2000. 
CHAPMAN, D.; NEWTON, M.; SACCO, P.; NOSAKA, K. Greater muscle damage induced by fast versus slow velocity eccentric exercise. International Journal of Sports Medicine, v.27, n.8, p.591-8, 2006.

CHAPMAN, D.W.; NEWTON, M.; MCGUIGAN, M.; NOSAKA, K. Effect of lengthening contraction velocity on muscle damage of the elbow flexors. Medicine and Science in Sports and Exercise, v.40, n.5, p.926-33, 2008.

CORRADETTI, M.N.; GUAN, K.L. Upstream of the mammalian target of rapamycin: do all roads pass through mTOR? Oncogene, v.25, n.48, p.6347-60, 2006.

CREWTHER, B.; CRONIN, J.; KEOGH, J. Possible stimuli for strength and power adaptation: acute mechanical responses. Sports Medicine, v.35, n.11, p.967-89, 2005.

CUTHBERTSON, D.; SMITH, K.; BABRAJ, J.; LEESE, G.; WADDELL, T.; ATHERTON, P.; WACKERHAGE, H.; TAYLOR, P.M.; RENNIE, M.J. Anabolic signaling deficits underlie amino acid resistance of wasting, aging muscle. FASEB Journal, v.19, n.3, p.422-4, 2005. 
DRUMMOND, M.J.; MIYAZAKI, M.; DREYER, H.C.; PENNINGS，B.; DHANANI, S.; VOLPI, E.; ESSER, K.A.; RASMUSSEN, B.B. Expression of growth-related genes in young and old human skeletal muscle following an acute stimulation of protein synthesis. Journal of Applied Physiology, (Epub), 2008.

EDMAN, K.A. Double-hyperbolic force-velocity relation in frog muscle fibres. Journal of Physiology, v.404, p.301-21, 1988.

EDMAN, K.A.P. Contractile performances of skeletal muscle fibres. . In: P. V. Komi. The Encyclopedia of Sports Medicine III: Strength and Power in Sports. Oxford: Blackwell Scientific, 1992, p.96-129.

ELIASSON, J.; ELFEGOUN, T.; NILSSON, J.; KOHNKE, R.; EKBLOM, B.; BLOMSTRAND, E. Maximal lengthening contractions increase p70 S6 kinase phosphorylation in human skeletal muscle in the absence of nutritional supply. American Journal of Physiology - Endocrinology and Metabolism, v.291, n.6, p.E1197-205, 2006.

ENOKA, R.M. Neuromechanics of human movement. Champaign: Human Kinetics, 2002. 
FARTHING, J.P.; CHILIBECK, P.D. The effects of eccentric and concentric training at different velocities on muscle hypertrophy. European Journal of Applied Physiology, v.89, n.6, p.578-86, 2003.

FUJITA, S.; DREYER, H.C.; DRUMMOND, M.J.; GLYNN, E.L.; CADENAS, J.G.; YOSHIZAWA, F.; VOLPI, E.; RASMUSSEN, B.B. Nutrient signalling in the regulation of human muscle protein synthesis. Journal of Physiology, v.582, n.Pt 2, p.813-23, 2007.

GILLIES, E.M.; PUTMAN, C.T.; BELL, G.J. The effect of varying the time of concentric and eccentric muscle actions during resistance training on skeletal muscle adaptations in women. European Journal of Applied Physiology, v.97, n.4, p.443-53, 2006.

GLASS, D.J. Signalling pathways that mediate skeletal muscle hypertrophy and atrophy. Nature Cell Biology, v.5, n.2, p.87-90, 2003.

GOLDSPINK, G. Changes in muscle mass and phenotype and the expression of autocrine and systemic growth factors by muscle in response to stretch and overload. Journal of Anatomy, v.194 ( Pt 3), p.323-34, 1999. 
Mechanical signals, IGF-I gene splicing, and muscle adaptation. Physiology (Bethesda), v.20, p.232-8, 2005.

GORDON, A.M.; HUXLEY, A.F.; JULIAN, F.J. The variation in isometric tension with sarcomere length in vertebrate muscle fibres. Journal of Physiology, v.184, n.1, p.170-92, 1966.

GUDI, S.; NOLAN, J.P.; FRANGOS, J.A. Modulation of GTPase activity of G proteins by fluid shear stress and phospholipid composition. Proceedings of the National Academy of Sciences of the United States of America, v.95, n.5, p.2515-9, 1998.

HAMEED, M.; ORRELL, R.W.; COBBOLD, M.; GOLDSPINK, G.; HARRIDGE, S.D. Expression of IGF-I splice variants in young and old human skeletal muscle after high resistance exercise. Journal of Physiology, v.547, n.Pt 1, p.247-54, 2003.

HAMILL, O.P.; MARTINAC, B. Molecular basis of mechanotransduction in living cells. Physiological Reviews, v.81, n.2, p.685-740, 2001. 
HEINEMEIER, K.M.; OLESEN, J.L.; HADDAD, F.; LANGBERG, H.; KJAER, M.; BALDWIN, K.M.; SCHJERLING, P. Expression of collagen and related growth factors in rat tendon and skeletal muscle in response to specific contraction types. Journal of Physiology, v.582, n.Pt 3, p.1303-16, 2007a.

HEINEMEIER, K.M.; OLESEN, J.L.; SCHJERLING, P.; HADDAD, F.; LANGBERG, H.; BALDWIN, K.M.; KJAER, M. Short-term strength training and the expression of myostatin and IGF-I isoforms in rat muscle and tendon: differential effects of specific contraction types. Journal of Applied Physiology, v.102, n.2, p.573-81, 2007b.

HERZOG, W. History dependence of force production in skeletal muscle: a proposal for mechanisms. Journal of Electromyography and Kinesiology, v.8, n.2, p.111-7, 1998.

HIGBIE, E.J.; CURETON, K.J.; WARREN, G.L., 3RD; PRIOR, B.M. Effects of concentric and eccentric training on muscle strength, cross-sectional area, and neural activation. Journal of Applied Physiology, v.81, n.5, p.2173-81, 1996. 
HORNBERGER, T.A.; CHIEN, S. Mechanical stimuli and nutrients regulate rapamycin-sensitive signaling through distinct mechanisms in skeletal muscle. Journal of Cell Biochemistry, v.97, n.6, p.1207-16, 2006.

HORNBERGER, T.A.; ESSER, K.A. Mechanotransduction and the regulation of protein synthesis in skeletal muscle. Proceedings of the Nutrition Society, v.63, n.2, p.331-5, 2004.

HORNBERGER, T.A.; STUPPARD, R.; CONLEY, K.E.; FEDELE, M.J.; FIOROTTO, M.L.; CHIN, E.R.; ESSER, K.A. Mechanical stimuli regulate rapamycin-sensitive signalling by a phosphoinositide 3-kinase-, protein kinase Band growth factor-independent mechanism. Biochemistry Journal, v.380, n.Pt 3, p.795-804, 2004.

HORTOBAGYI, T.; BARRIER, J.; BEARD, D.; BRASPENNINCX, J.; KOENS, P.; DEVITA, P.; DEMPSEY, L.; LAMBERT, J. Greater initial adaptations to submaximal muscle lengthening than maximal shortening. Journal of Applied Physiology, v.81, n.4, p.1677-82, 1996. 
HOWELL, J.N.; FUGLEVAND, A.J.; WALSH, M.L.; BIGLAND-RITCHIE, B. Motor unit activity during isometric and concentric-eccentric contractions of the human first dorsal interosseus muscle. Journal of Neurophysiology, v.74, n.2, p.901-4, 1995.

JOUMAA, V.; RASSIER, D.E.; LEONARD, T.R.; HERZOG, W. The origin of passive force enhancement in skeletal muscle. American Journal of Physiology - Cell Physiology, v.294, n.1, p.C74-8, 2008.

KIMBALL, S.R.; FARRELL, P.A.; JEFFERSON, L.S. Invited Review: Role of insulin in translational control of protein synthesis in skeletal muscle by amino acids or exercise. Journal of Applied Physiology, v.93, n.3, p.1168-80, 2002.

KNUTTGEN, H.G.A.K., P.V. Basic Definitions for Exercise. In: P. V. Komi. The Encyclopedia of Sports Medicine III: Strength and Power in Sports. Oxford: Blackwell Scientific Publications, 1992, p.17-22.

KOMI, P.V. Measurement of force-velocity relationship in human muscle under concentric and eccentric contractions. In: S. Cerquiglini, Vernerando, A. Biomechanics III. Basel: Karger, 1973, p.224-229. 
KOOPMAN, R.; ZORENC, A.H.; GRANSIER, R.J.; CAMERON-SMITH, D.; VAN LOON, L.J. Increase in S6K1 phosphorylation in human skeletal muscle following resistance exercise occurs mainly in type II muscle fibers. American Journal of Physiology - Endocrinology and Metabolism, v.290, n.6, p.E1245$52,2006$.

LIU, Y.; HEINICHEN, M.; WIRTH, K.; SCHMIDTBLEICHER, D.; STEINACKER, J.M. Response of growth and myogenic factors in human skeletal muscle to strength training. British Journal of Sports Medicine, v.42, n.12, p.989-93, 2008.

LYNCH, G.S.; FAULKNER, J.A. Contraction-induced injury to single muscle fibers: velocity of stretch does not influence the force deficit. American Journal of Physiology, v.275, n.6 Pt 1, p.C1548-54, 1998.

MACDOUGALL, J.D. Adaptability of muscle to strength training - a cellular approach. In: B. Saltin. Biochemistry of Exercise VI. Illinois: Human Kinetics, 1986, p.501-513. 
MCCULLY, K.K.; FAULKNER, J.A. Characteristics of lengthening contractions associated with injury to skeletal muscle fibers. Journal of Applied Physiology, v.61, n.1, p.293-9, 1986.

MORGAN, D.L. New insights into the behavior of muscle during active lengthening. Biophysical Journal, v.57, n.2, p.209-21, 1990.

MORGAN, D.L.; PROSKE, U. Popping sarcomere hypothesis explains stretchinduced muscle damage. Clinical and Experimental Pharmacology and Physiology, v.31, n.8, p.541-5, 2004.

MORGAN, J.E.; PARTRIDGE, T.A. Muscle satellite cells. International Journal of Biochemestry and Cell Biology, v.35, n.8, p.1151-6, 2003.

NADER, G.A.; MCLOUGHLIN, T.J.; ESSER, K.A. mTOR function in skeletal muscle hypertrophy: increased ribosomal RNA via cell cycle regulators. American Journal of Physiology - Cell Physiology, v.289, n.6, p.C1457-65, 2005. 
NARDONE, A.; ROMANO, C.; SCHIEPPATI, M. Selective recruitment of highthreshold human motor units during voluntary isotonic lengthening of active muscles. Journal of Physiology, v.409, p.451-71, 1989.

NARDONE, A.; SCHIEPPATI, M. Shift of activity from slow to fast muscle during voluntary lengthening contractions of the triceps surae muscles in humans. Journal of Physiology, v.395, p.363-81, 1988.

NOSAKA, K.; CLARKSON, P.M. Muscle damage following repeated bouts of high force eccentric exercise. Medicine and Science in Sports and Exercise, v.27, n.9, p.1263-9, 1995.

NOSAKA, K.; SAKAMOTO, K.; NEWTON, M.; SACCO, P. How long does the protective effect on eccentric exercise-induced muscle damage last? Medicine and Science in Sports and Exercise, v.33, n.9, p.1490-5, 2001.

PADDON-JONES, D.; LEVERITT, M.; LONERGAN, A.; ABERNETHY, P. Adaptation to chronic eccentric exercise in humans: the influence of contraction velocity. European Journal of Applied Physiology, v.85, n.5, p.466-71, 2001. 
PARSONS, S.A.; MILLAY, D.P.; WILKINS, B.J.; BUENO, O.F.; TSIKA, G.L.; NEILSON, J.R.; LIBERATORE, C.M.; YUTZEY, K.E.; CRABTREE，G.R.; TSIKA, R.W.; MOLKENTIN, J.D. Genetic loss of calcineurin blocks mechanical overload-induced skeletal muscle fiber type switching but not hypertrophy. Journal of Biological Chemistry, v.279, n.25, p.26192-200, 2004.

PETTE, D.; STARON, R.S. Myosin isoforms, muscle fiber types, and transitions. Microscopy Research and Technique, v.50, n.6, p.500-9, 2000.

RENNIE, M.J.; WACKERHAGE, H.; SPANGENBURG, E.E.; BOOTH, F.W. Control of the size of the human muscle mass. Annual Review of Physiology, v.66, p.799-828, 2004.

ROMMEL, C.; BODINE, S.C.; CLARKE, B.A.; ROSSMAN, R.; NUNEZ, L.; STITT, T.N.; YANCOPOULOS, G.D.; GLASS, D.J. Mediation of IGF-1induced skeletal myotube hypertrophy by $\mathrm{PI}(3) \mathrm{K} / \mathrm{Akt} / \mathrm{mTOR}$ and PI(3)K/Akt/GSK3 pathways. Nature Cell Biology, v.3, n.11, p.1009-13, 2001. 
SAKAMOTO, K.; ASCHENBACH, W.G.; HIRSHMAN, M.F.; GOODYEAR, L.J. Akt signaling in skeletal muscle: regulation by exercise and passive stretch. American Journal of Physiology - Endocrinology and Metabolism, v.285, n.5, p.E1081-8, 2003.

SARTORELLI, V.; FULCO, M. Molecular and cellular determinants of skeletal muscle atrophy and hypertrophy. Science's STKE: Signal Transduction Knowledge Environment, v.2004, n.244, p.re11, 2004.

SCHIAFFINO, S.; REGGIANI, C. Myosin isoforms in mammalian skeletal muscle. Journal of Applied Physiology, v.77, n.2, p.493-501, 1994.

SCHMELZLE, T.; HALL, M.N. TOR, a central controller of cell growth. Cell, v.103, n.2, p.253-62, 2000.

SEGER, J.Y.; ARVIDSSON, B.; THORSTENSSON, A. Specific effects of eccentric and concentric training on muscle strength and morphology in humans. European Journal of Applied Physiology and Occupational Physiology, v.79, n.1, p.49-57, 1998. 
SHEPSTONE, T.N.; TANG, J.E.; DALLAIRE, S.; SCHUENKE, M.D.; STARON, R.S.; PHILLIPS, S.M. Short-term high- vs. low-velocity isokinetic lengthening training results in greater hypertrophy of the elbow flexors in young men. Journal of Applied Physiology, v.98, n.5, p.1768-76, 2005.

SPANGENBURG, E.E.; MCBRIDE, T.A. Inhibition of stretch-activated channels during eccentric muscle contraction attenuates p70S6K activation. Journal of Applied Physiology, v.100, n.1, p.129-35, 2006.

TERZIS， G.; GEORGIADIS， G.; STRATAKOS， G.; VOGIATZIS， I.; KAVOURAS, S.; MANTA, P.; MASCHER, H.; BLOMSTRAND, E. Resistance exercise-induced increase in muscle mass correlates with p70S6 kinase phosphorylation in human subjects. European Journal of Applied Physiology, v.102, n.2, p.145-52, 2008.

TIDBALL, J.G. Mechanical signal transduction in skeletal muscle growth and adaptation. Journal of Applied Physiology, v.98, n.5, p.1900-8, 2005. 
TOIGO, M.; BOUTELLIER, U. New fundamental resistance exercise determinants of molecular and cellular muscle adaptations. European Journal of Applied Physiology, v.97, n.6, p.643-63, 2006.

TOWBIN, H.; STAEHELIN, T.; GORDON, J. Electrophoretic transfer of proteins from polyacrylamide gels to nitrocellulose sheets: procedure and some applications. Proceedings of the National Academy of Sciences of the United States of America, v.76, n.9, p.4350-4, 1979.

WARREN, G.L.; HERMANN, K.M.; INGALLS, C.P.; MASSELLI, M.R.; ARMSTRONG, R.B. Decreased EMG median frequency during a second bout of eccentric contractions. Medicine and Science of Sports and Exercise, v.32, n.4, p.820-9, 2000.

WARREN, G.L.; LOWE, D.A.; ARMSTRONG, R.B. Measurement tools used in the study of eccentric contraction-induced injury. Sports Medicine, v.27, n.1, p.43-59, 1999.

WYMANN, M.P.; PIROLA, L. Structure and function of phosphoinositide 3kinases. Biochimica et Biophysica Acta, v.1436, n.1-2, p.127-50, 1998. 


\begin{abstract}
ANEXOS
ANEXO 1 - Questionário de avaliação do nível de treinamento dos sujeitos
\end{abstract}

Nome:

Data nascimento:

Altura:

Peso:

Pratica musculação? ( ) SIM ( ) NÃO

Pratica atividade (s) física (s) (exceto musculação)? ( ) SIM ( ) NÃO

Se SIM, qual (is)?

Qual a frequência semanal? Há quanto tempo?

Já praticou musculação? ( ) SIM （ ) NÃO

Se sim, há quanto tempo parou?

Faz uso de medicamentos? ( ) SIM ( ) NÃO

Se SIM, qual? Há quanto tempo?

Faz uso de suplementos alimentares? ( ) SIM ( ) NÃO

Se SIM, qual? Há quanto tempo?

Faz uso de esteróides anabolizantes? ( ) SIM ( ) NÃO

Tem algum histórico de lesão músculo-esquelética?

Se SIM, qual? 